\title{
Kulturotwórcza rola państwowych uczelni zawodowych. Od elitarnego do egalitarnego modelu studiów wyższych
}

W Stowniku języka polskiego termin kulturotwórczy jest zdefiniowany jako przyczyniający się do na tworzenia, rozwoju kultury ${ }^{\mathrm{I}}$. Badanie kulturotwórczej roli jest procesem wieloaspektowym, wymagającym wielu lat obserwacji danego zjawiska i jego społecznych skutków, a w wypadku instytucji opisania zmian zaistniałych w wyniku ich działalności. Instytucje edukacyjne, ze względu na swoje statutowe obowiązki przekazywania wiedzy i wychowywania kolejnych pokoleń, powinny realizować kulturotwórcze zadania wynikające z bieżących potrzeb danej społeczności oraz te określane w planach jej przyszłego rozwoju. Na potrzeby niniejszego opracowania przyjmuję termin kulturotwórcza w rozumieniu antropologicznym, czyli obejmującym całokształt dorobku - zarówno niematerialnego, jak i materialnego kultury². W odniesieniu do uczelni są to: działalność dydaktyczna, naukowa, organizacyjna pracowników i studentów, jak i materialne podstawy funkcjonowania uczelni - obiekty i ich wyposażenie.

Próbie opisania kulturotwórczej roli i znaczenia państwowych uczelni zawodowych w Polsce na przykładzie Państwowej Wyższej Szkoły Zawodowej im. Stanisława

1 Stownik jezyka polskiego, red. M. Szymczak, PWN, Warszawa 1978, s. I084.

2 Por. A. Kłoskowska, Kultura masowa, PWN, Warszawa 1980, s. 2I-23.

*Mgr Franciszek Tereszkiewicz - absolwent studiów w zakresie filologii polskiej na Uniwersytecie Jagiellońskim oraz studiów podyplomowych: Studium Filologii Polskiej, Studium Filozoficzno-Religioznawcze, Zarządzanie Szkolnictwem Wyższym. Kanclerz Państwowej Wyższej Szkoły Zawodowej im. Stanisława Pigonia w Krośnie od początku jej działalności statutowej. 
Pigonia w Krośnie ${ }^{3}$ sprzyjają moje osobiste doświadczenia zawodowe, obejmujące zarówno okres tworzenia uczelni, jak i jej dziewiętnastoletniej działalności, a także obserwacje i doświadczenia z wielu kontaktów w ramach rozlicznych form współpracy z innymi uczelniami o takim statusie ${ }^{4}$.

Do najważniejszych wyznaczników kulturowych determinujących przemiany szkolnictwa wyższego w minionym ćwierćwieczu w Polsce należą:

- europejski i krajowy popyt na absolwentów wyższych uczelni, zwłaszcza inżynierów, związany z dynamicznym rozwojem nowych technologii,

- umasowienie szkolnictwa wyższego,

- dynamiczny rozwój uczelni prywatnych i państwowych wyższych szkół zawodowych,

- popyt na kształcenie zawodowe i praktyczne,

- poważny kryzys studiów humanistycznych i humanistycznego kształcenia studentów studiów niehumanistycznych,

- głęboki kryzys demograficzny,

- reformy systemu szkolnictwa wyższego.

Refleksję nad kulturotwórczą rolą szkół wyższych w Polsce warto rozpocząć od przytoczenia wyników badań naukowców amerykańskich z drugiej połowy XX wieku, według których do najważniejszych zadań uniwersytetów należy zaliczyć: rozwijanie badań naukowych ze względu na ich autoteliczną wartość oraz na zaspokajanie potrzeb społeczeństwa, rozwijanie zdolności oraz intelektualnych i zawodowych potrzeb studentów, podnoszenie możliwości działania człowieka w społeczeństwie, kształtowanie poziomu kulturalnego i moralnego społeczeństwa, a także zwiększanie sprawiedliwości społecznej przez wyrównywanie szans uzyskania wykształcenias. Poglądy te znacząco wpłynęły na rozwój światowego szkolnictwa wyższego. Według Tomasza Goban-Klasa

Pod koniec XX wieku wzorem Ameryki rozpoczął się proces szerokiej demokratyzacji szkolnictwa wyższego, motywowany zarówno względami egalitaryzmu społecznego, jak i - bardziej - rosnącymi potrzebami rozwoju intelektualizacji pracy i życia we wszystkich dziedzinach... Nie wystarcza już matura, potrzebny jest licencjat. Tak właśnie myślą Amerykanie, uznając znaczne upowszechnienie kształcenia ponadlicealnego w tzw. community colleges za zadanie narodowe ${ }^{6}$.

Krzysztof Leja wyraźnie wskazuje na trzy zadania w misji uczelni:

3 W dalszej części tekstu będę używał skrótu PWSZ, odwołując się do ww. jako kategorii zbiorowej i PWSZ w... odwołując się do wybranej uczelni.

4 Przygodę intelektualną i organizacyjną z PWSZ w Krośnie rozpocząłem od powierzenia mi funkcji pełnomocnika wojewody krośnieńskiego ds. utworzenia PWSZ w Krośnie po pełnienie funkcji kanclerza od początku działalności uczelni.

5 Por. A. Touraine, The Academic System in American Society, New York 1974.

6 T. Goban-Klas, Uniwersytet w kontekście nowych mediów i technologii informacyjnych, [w:] Idea uniwersytetu. Reaktywacja, red. P. Sztompka, K. Matuszek, Wydawnictwo Uniwersytetu Jagiellońskiego, Kraków 20I5, s. 300. 
Współczesna uczelnia ma do wypełnienia trzy misje, z których pierwszą jest kształcenie, drugą działalność naukowo-badawcza, a trzecią kreowanie wzajemnych relacji z otoczeniem, których efektem ma być upowszechnianie i popularyzacja wyników badań oraz ich wdrażanie, w tym komercjalizacja ${ }^{7}$.

Podkreślenie wagi trzeciej misji, a właściwie zrównanie jej z dwiema pierwszymi zostało przez Krzysztofa Leję szerzej rozwinięte o aspekty komercjalizowania wyników badań naukowych:

Trzecia misja uczelni wpisuje się w odpowiedzialność uczelni za rozwój społeczny i ekonomiczny kraju. Przejawiać się ona powinna zarówno odpowiedzią uczelni na oczekiwania otoczenia (user-directed commercialization) jak i zdolnością do komercjalizacji osiągnięć naukowych (science-directed commercialization). Magnus Gulbradsen i Stig Slipersæter (w monografii pod redakcją Andrea Bonaccorsi i Cinzia Daraio pt. Universities and strategic knowledge creation. Specialization and Performance in Europe, Edward Elgar, 2007) proponują w przypadku user-directed mierzyć efektywność trzeciej misji m.in. za pomocą takich wskaźników jak: przychody badawcze uczelni podchodzące z gospodarki, aktywne umowy o współpracy uczelni z gospodarką, ekspertyzy wykonane dla gospodarki, publikacje naukowe dotyczące obszarów zainteresowania gospodarki. W przypadku science-directed proponowane mierniki to m.in. liczba patentów opracowanych w uczelni, przychody z licencji, firmy typu spin-off, których właścicielami jest uczelnia, ustalone zasady redystrybucji przychodów z komercjalizacji oraz możliwość uzyskiwania stopnia doktora przez osoby z gospodarki (tzw. doktoraty przemysłowe). Problem w tym, że trzecia misja w polskich uczelniach jest niedocenianym i niskopunktowanym zajęciem nauczycieli akademickich, którzy większość czasu poświęcają dydaktyce i badaniom naukowym, w oderwaniu od ich praktycznej użyteczności (ponieważ ocena praktycznej użyteczności działań naukowca nie przekłada się na ocenę jakości pracy tego naukowca) ${ }^{8}$.

Tak wyraźne podkreślenie materialnego, komercyjnego wymiaru działania uczelni zachęca do podjęcia próby szerszego omówienia pozytywnych przykładów rozwijania zarówno bazy badawczej, jak i finansowych efektów uprawiania nauki.

Dla celów niniejszego opracowania, rozważania nad kulturotwórczą rolą szkolnictwa wyższego zostaną ograniczone do publicznych uczelni zawodowych prowadzących działalność w Polsce od kilkunastu lat (najstarsze od i998), najczęściej poza ośrodkami akademickimi, co w oczywisty sposób ogranicza możliwości, jak i obszar ich oddziaływania. Jak można sądzić, z tego powodu ambicje kulturotwórcze i wynikające z nich zobowiązania wobec lokalnych społeczności, zapisane w strategicznych dokumentach tych uczelni są formułowane na dużym poziomie ogólności.

7 K. Leja, Trzy misje uczelni. Trzy ścieżki kariery, „Forum Akademickie” 2015, nr I, s. 22.

8 Tamże. 
Dla zrozumienia dynamiki i kierunków przemian wyższego szkolnictwa zawodowego w Polsce po 1990 roku konieczne jest przypomnienie dwóch najważniejszych zmian ustawowych, tj. ustawy $O$ szkolnictwie wyższym z dnia I2 września 1990 roku i ustawy $O$ wyzszych szkotach zawodowych z dnia 26 czerwca 1997.

Ustawa z 1990 dawała prawo do zakładania uczelni niepaństwowych: Art. Is Uczelnię niepaństwowa może zatożyć osoba fizyczna lub osoba prawna, zwana dalej „zatożycielem”, na podstawie pozwolenia udzielanego przez ministra wtaściwego do spraw szkolnictwa wyższego, po zasięgnięciu opinii Państwowej Komisji Akredytacyjnej. Zapisy ustawy umożliwiły szybki rozwój prywatnego szkolnictwa wyższego - odpłatnego, lokowanego głównie w większych ośrodkach miejskich. Na spektakularny sukces prywatnych uczelni wyższych złożyło się wiele czynników, m.in. aspiracje społeczne kolejnych roczników maturzystów wyżu demograficznego lat dziewięćdziesiątych, dla których brakowało miejsc w publicznych uczelniach akademickich, oferta dydaktyczna obejmująca atrakcyjne specjalności studiów (związane głównie z zarządzaniem, marketingiem czy informatyką stosowaną), współpraca z uczelniami zagranicznymi, a także interesujące formy praktyk zawodowych, często zagranicznych. Bardzo dynamiczny, wręcz niekontrolowany rozwój tych uczelni dowodnie wykazał, że inwestowanie w rozwój szkolnictwa wyższego może stanowić atrakcyjną finansowo działalność. Liberalizując rynek prywatnego szkolnictwa wyższego, przepisy ustawy z roku 1990 doprowadziły w efekcie do powstania liczebnej przewagi wyższych uczelni prywatnych nad państwowymi, nie poprawiając równocześnie dostępu do studiów dla młodzieży pochodzącej ze wsi i małych miast, dla której wysokie koszty studiów w uczelniach prywatnych (zazwyczaj prowadzących działalność w dużych miastach) stanowiły nieprzekraczalną barierę. Zapisy wspomnianej ustawy umożliwiały uczelniom, również państwowym, prowadzenie studiów zawodowych, ale nie pozwalały na tworzenie uczelni państwowych kształcących wyłącznie na poziomie I stopnia studiów.

W tej sytuacji przyjęcie przez Sejm RP 26 czerwca 1997 ustawy O wyższych szkotach zawodowych, poprzedzone wnikliwą analizą doświadczeń niemieckich, stworzyło prawne warunki do tworzenia państwowych szkół zawodowych ${ }^{\text {10 }}$, kształcących studentów do poziomu wyższego zawodowego, tj. licencjata i inżyniera. Jak oczekiwana była to ustawa, świadczy dynamika tworzenia takich uczelni - w roku 1998 powstało ich dziewięć, w 1999 pięć, a w latach 2000-2007 dwadzieścia jeden. Łącznie utworzono 36 państwowych szkół zawodowych. Zostały one w miarę równomiernie rozmieszczone na terenie całego kraju, tworząc nową ofertę kierunków i specjalności ${ }^{\text {II }}$, i w krótkim czasie osiągnęły wysoką jakość kształcenia.

9 Łącznie w Polsce utworzono 38I wyższych uczelni prywatnych, z których w roku akademickim 2017/20I7 pozostało 253 (302 łącznie ze znajdującymi się w likwidacji).

10 Por. C. Królikowski, Ustawa z 26 czerwca 1997 roku o wyższych szkotach zawodowych - geneza, [w:] Udana Dekada. Państwowe Wyższe Szkoty Zawodowe w Polsce 1998-2008, Ciechanów-Krosno 2008, s. I7-19.

11 PWSZ, w przeciwieństwie do uczelni niepublicznych, oferowały inżynierskie kierunki studiów, wymagające kosztownej bazy i wyposażenia dydaktycznego. 
Powstanie i rozwój samodzielnych instytucji naukowo-dydaktycznych w miastach średniej wielkości (30- Ioo tys. mieszkańców), w których często nie było tradycji kształcenia na poziomie studiów wyższych, ułatwiło podejmowanie studiów młodzieży zamieszkującej prowincję kraju. W wypadku PWSZ w Krośnie znalazło to odzwierciedlenie we wpisanych w jej misję mottach „Uczelnia na miejscu”, „Wiedza blisko Ciebie”. Istotne było również podniesienie współczynnika skolaryzacji w małych miastach i wsiach. W aspekcie moralnym i politycznym są to efekty ważne dla realizowania w praktyce zasady sprawiedliwości społecznej. Ponadto utworzenie tych uczelni znacząco wpłynęło na rozwój urbanistyczny, gospodarczy i demograficzny miast, m. in. przez budowę i rozbudowę obiektów uczelnianych, stworzenie nowych miejsc pracy oraz zahamowanie migracji młodych ludzi do większych miast bądź za granicę. Dla przykładu - wojewoda krośnieński we wniosku o utworzenie uczelni w Krośnie argumentował:

Powołanie Państwowej Wyższej Szkoły Zawodowej w Krośnie jest szczególnie istotne dla naszego regionu. W przyszłym województwie podkarpackim byłaby to jedna z dwóch - obok obecnej Wyższej Szkoły Pedagogicznej w Rzeszowie - szkół wyższych kształcących nauczycieli oraz jedna z niewielu kształcących inżynierów poszukiwanych specjalności. Istnienie ich ma kapitalne znaczenie dla wielkiego, lecz zaniedbanego kulturalnie regionu, z ubogą ludnością wiejską, z rzeszami młodzieży pozbawionej możliwości zdobywania wykształcenia w wielkich, odległych od miejsc jej zamieszkania ośrodkach akademickich. Dla młodzieży z rodzin dotkniętych bezrobociem, pochodzącej z drobnych gospodarstw, istnienie szkoły wyższej w pobliżu miejsca zamieszkania, do której mogłaby uczęszczać bez konieczności wyjazdu i zamieszkania w Krakowie czy Rzeszowie, z czym wiążą się znaczne koszty, jest jedyną szansą na podjęcie studiów, zdobycie wykształcenia, a w przyszłości na awans społeczny i uzyskanie godziwej pracy. Z tych samych powodów również nauczyciele szkół podstawowych mogliby łatwiej podnosić swe kwalifikacje. Trzeba pamiętać o tym, że nawet w wypadku zaistnienia kilku szkół wyższych województwo podkarpackie w porównaniu z sąsiednim województwem małopolskim (Uniwersytet Jagielloński, kilkanaście wyższych szkół akademickich, wyższe szkoły zawodowe w Krakowie. Tarnowie i Nowym Sączu) w dalszym ciągu stanowiłoby pod tym względem rodzaj pustyni ${ }^{\mathrm{I2}}$.

Następnie, już w szerszej perspektywie regionu Podkarpacia, jako marszałek województwa podkarpackiego w aneksie do powyższego wniosku uzupełniał:

Region Podkarpacia wymaga wsparcia szczególnie w zakresie rozwoju szkół, które umożliwią tutejszej młodzieży zdobywanie wykształcenia bez konieczności podejmowania coraz kosztowniejszych studiów w ośrodkach akademickich, położonych

12 B. Rzońca, Wojewoda Krośnieński, Załącznik do wniosku o utworzenie Państwowej Wyższej Szkoły Zawodowej w Krośnie, Krosno 1998. 
daleko od miejsca zamieszkania. Jestem przekonany, że inwestowanie w oświatę i naukę przyniesie dobre owoce i stworzy solidne podstawy do rozwoju tej części kraju ${ }^{13}$.

Pozytywne aspekty utworzenia uczelni wysoko oceniali również przedstawiciele miejskich władz samorządowych, przewidując, że działalność uczelni wniesie w życie miasta nowe wyzwania, ale i nowe inspiracje - zwiększenie populacji mieszkańców ${ }^{\mathrm{I}}$, szerszą ofertę kulturalną i sportową oraz działalność związaną z otoczeniem socjalnym uczelni. Można wnioskować, że podobną motywacją kierowały się władze innych województw. Rządowy plan tworzenia państwowych wyższych szkół zawodowych w miastach tracących status stolicy województwa został zrealizowany w zdecydowanej większości (85\%) likwidowanych w wyniku reformy administracyjnej województw ${ }^{15}$. Ten wysoki współczynnik świadczy o tym, jak ówczesne władze administracyjne doceniły i twórczo wykorzystały możliwości. W kilku wypadkach utworzono uczelnie w miastach, które nie spełniały tego warunku ${ }^{16}$, co spowodowało, że w niektórych regionach kraju (Dolny Śląsk, Podkarpacie) ze względu na niż demograficzny, uczelnie zawodowe nie mogły osiągnąć planowanych wyników rekrutacji.

\section{Ksztattowanie struktur organizacyjnych}

Tworzenie podstaw funkcjonowania PWSZ w nowych ośrodkach miało wyraźne, choć niełatwo osiągane, znamiona działalności kulturotwórczej. Istotnym dla nowo tworzonych uczelni czynnikiem warunkującym ich sprawne funkcjonowanie było organizowanie od podstaw „ładu akademickiego”. Pod tym pojęciem autorzy raportu Diagnoza stanu szkolnictwa wyższego w Polsce rozumieją system wdrażania za pomocą różnorodnych instrumentów (prawo, instrumenty ekonomiczne, dobre praktyki, obyczaje, doświadczenie) decyzji i rozwiązań organizacyjnych funkcjonowania szkolnictwa wyższego ${ }^{17}$. Tworzenie ładu akademickiego należy rozpatrywać w dwóch perspektywach - zewnętrznej, tworzonej przez organy państwa odpowiedzialne za szkolnictwo wyższe i otoczenie społeczne uczelni oraz wewnętrznej, tworzonej przez władze uczelni i jej pracowników ${ }^{18}$.

Realizacja tych zadań była poważnym wyzwaniem zarówno dla organów zewnętrznych, głównie dla pracowników Ministerstwa Edukacji Narodowej ${ }^{19}$, Państwowej

13 B. Rzońca, Marszałek Województwa Podkarpackiego, Załącznik do wniosku o utworzenie PWSZ w Krośnie, OP.IV-0715(I)99, Rzeszów 26 maja 1999.

14 W latach 2008-2013 w PWSZ w Krośnie studiowało ponad 4500 osób, co stanowiło niemal IO\% populacji mieszkańców.

15 Państwowych szkół zawodowych nie utworzono w następujących tracących status stolicy województwa miast: Częstochowie, Ostrołęce, Piotrkowie, Radomiu, Siedlcach, Sieradzu i Słupsku.

16 W Gnieźnie, Głogowie, Jarosławiu, Nysie, Raciborzu, Sandomierzu, Sanoku, Wałczu.

17 Diagnoza stanu szkolnictwa wyższego w Polsce, Ernst \& Young, IbnGR, Warszawa 2009, s. Io.

18 Por. B. Kożuch, Zmiany zachowań organizacyjnych pod wptywem oczekiwań interesariuszy uczelni akademickich, [w:] Wyzwania zarzadzania jakościa w szkotach wyższych, red. T. Wawak, Wydawnictwo Uniwersytetu Jagiellońskiego, Kraków 20II, s. 55 . 
Komisji Akredytacyjnej, jak i dla władz i wewnętrznego środowiska uczelni. Warto przypomnieć, że wizytatorzy PKA przeprowadzali kontrole, sprawdzali przydatność i stan infrastruktury i wydawali opinię przed utworzeniem uczelni oraz po pierwszym roku działalności dydaktycznej. Innym korzystnym czynnikiem wsparcia było życzliwe, także materialne, zaangażowanie wojewódzkich i powiatowych organów samorządowych ${ }^{20}$ oraz miejscowych podmiotów gospodarczych. Ważną część doświadczeń organizacyjnych zdobywano w ramach działań integrujących porządki zewnętrzny i wewnętrzny - w toku dyskusji organizowanych w ramach Konferencji Rektorów Państwowych Szkół Zawodowych, ogólnopolskich konferencji kanclerzy i kwestorów organizowanych przez MEN oraz w różnorodnych formach współpracy naukowej i organizacyjnej z uczelniami akademickimi. Doświadczenia tam zdobywane wpływały na kulturę organizacyjną uczelni zawodowych ${ }^{21}$. Kształtowanie kultury akademickiej PWSZ obejmowało przyswojenie wartości i norm, a także symboli i rytuałów wypracowanych w wielowiekowej tradycji akademickiej. W kręgu wartości szczególnie mocno i wyraźnie podkreślano rzetelność w wypełnianiu obowiązków dydaktycznych, konieczność wychowywania studentów w duchu wolności, odpowiedzialności i solidności, a także w poszanowaniu wartości wiedzy i badań naukowych, etosu badacza i nauczyciela. Jak wynika z kilkunastu lat doświadczeń, wypracowanie, uznanie i praktykowanie etosu akademickiego jest nadal jednym z najważniejszych zadań i celów społeczności uczelni. Zadaniem tym trudniejszym, że realizowanym w czasie żywiołowej transformacji ustrojowej, gospodarczej, społecznej i obyczajowej w Polsce po 1989 roku.

\section{Spoteczność państwowych szkót zawodowych uczelni - zadania i wyzwania}

Piotr Sztompka definiuje kulturę akademicką jako ramy ideowe i normatywne wyznaczające pole aktywności spoteczności uniwersyteckiej22. Siła kultury akademickiej, wyrastająca z wielowiekowej tradycji, ma źródła w historii, etosie zakorzenionym w badaniach naukowych i działalności dydaktycznej oraz w rozwiniętych, a zarazem spetryfikowanych strukturach organizacyjnych. Etos akademicki to wewnętrzna aksjologia badaczy i nauczycieli akademickich, na którą sktadają się przekonania, normy, postawy i zinstytucjonalizowane praktyki stużace realizacji wartości poznawczych, przede wszystkim poszukiwania prawdy ${ }^{23}$. W wypadku uczelni rozpoczynających działalność

20 Samorząd Województwa Podkarpackiego przekazał na rzecz uczelni w formie darowizny nieruchomości wraz budynkami o łącznej powierzchni I,03 ha, a Gmina Krosno, także w formie darowizny, nieruchomości wraz budynkami o łącznej powierzchni 7,39 ha.

21 Kultura organizacyjna w sensie ogólnym rozumiana jako system założeń, wartości i norm społecznych, będących stymulatorami tych zachowań członków organizacji, które są istotne z punktu widzenia realizacji fundamentalnie przyjętych celów. Cyt. za: Cz. Sikorski, Zachowania ludzi w organizacji, Wydawnictwo Naukowe PWN, Warszawa 1999, s. 235.

22 P. Sztompka, Uniwersytet wspótczesny: zderzenie dwóch kultur, [w:] Idea uniwersytetu. Reaktywacja, dz. cyt., s. I8.

23 Program rozwoju szkolnictwa wyższego do 2020 r., część II. Misja spoteczna uniwersytetu w XXI wieku, red. A. Szostek, Warszawa 2015, s. II. 
w środowiskach, w których nie było doświadczeń ani tradycji akademickich, kształtowanie podstaw kultury akademickiej było trudne. Najważniejszym zadaniem w tym procesie było integrowanie pracowników i studentów w świadomą swoich celów a zarazem odrębności wspólnotę. Oprócz materialnych i zewnętrznych atrybutów, takich jak obiekty, nazwa czy logo - chodziło o przyjęcie wartości i norm uznawanych i podzielanych przez jej członków i wyznaczających relacje między nimi, wzory osobowe i kulturę organizacyjną.

Te wartości i wzorce musiały być, przynajmniej na początku działalności, wdrażane przez pracowników uczelni akademickich w nowo tworzonych uczelniach, a później dopiero wzbogacone o własne doświadczenia bądź lokalne tradycje. Ponieważ w PWSZ zatrudniano pracowników z różnych uczelni akademickich, reprezentowali oni różne, typowe dla ich uczelni macierzystych tradycje akademickie i wzory zachowań. Kształtowanie wspólnoty dokonywało się również przy opracowywaniu dokumentów prawnych konstytuujących uczelnię, tj. statutu, regulaminu posiedzeń senatu, regulaminu studiów, a w późniejszym czasie kodeksu etyki. Zwłaszcza dyskusja nad kodeksami etyki, zapoczątkowana w uczelniach akademickich ${ }^{24}$, a będąca wyrazem kryzysu wartości akademickich, przyczyniła się jeśli nie do rozwiązania problemu, to przynajmniej do pogłębienia świadomości erozji tych wartości i imperatywie ich odbudowywania. Ważnym zadaniem w tym zakresie były starania władz uczelni o przestrzeganie punktualności, odpowiedzialności, życzliwości i uprzejmości, ale i stawianie wysokich wymagań studentom w zakresie dbałości o kulturę języka. Duże oczekiwania wobec umiejętności dydaktycznych i metodycznych nauczycieli, narzucają wniosek, że niedopatrzeniem prawnym jest brak wymogu posiadania przez nich przygotowania pedagogicznego. Nauczyciele bez przygotowania dydaktycznego skazani są często na intuicyjne poszukiwanie sposobów na osiąganie lepszych wyników dydaktycznych, lub powielanie wprost wzorów metodycznych zapamiętanych z własnych studiów. Wydaje się, że nawet krótki kurs z podstaw dydaktyki uczelni wyższej byłby optymalnym rozwiązaniem umożliwiającym im osiąganie lepszej jakości kształcenia, a zarazem standaryzującym ogólne zasady pracy w uczelni.

Jednym z najważniejszych zadań, a może nawet warunkiem - sine qua non skutecznego działania nowo powstałych uczelni jest utożsamianie się pracowników i studentów z misją uczelni i niełatwy proces integrowania społeczności. Znaczenie wzorów osobowych pracowników uczelni podkreślał Franciszek Ziejka, pisząc: $w$ każdym czasie, w kazdej epoce, także i dzisiaj, prawdziwy autorytet moralny uniwersytetu buduja cztonkowie jego wspólnoty akademickiej, którzy w niej pracują i studiuja! Jeśli oni zawioda, na nic zdadza się nawet najszacowniejsze budynki, czy najpiękniejsza historia ${ }^{25}$.

$\mathrm{Z}$ podobną troską i niepokojem o odpowiedzialności za jakość pracy ze studentami pisał A. Białas:

24 Akademicki kodeks wartości został przyjęty przez Senat Uniwersytetu Jagiellońskiego w dniu 25 czerwca 2013 roku.

25 F. Ziejka, Czy można dziś jeszcze mówić o dostojensstwie uniwersytetu, [w:] Idea uniwersytetu. Reaktywacja, dz. cyt., s. 52. 
Aby więc zrealizować prawdziwą misję uczelni, trzeba przede wszystkim zadbać o to, aby zespół jej pracowników uczył najlepiej jak potrafi. Aby dobre wykształcenie studenta było absolutnym priorytetem. Aby praca ze studentem była właściwie oceniana, doceniana, wynagradzana wreszcie. Aby powstała atmosfera w której praca dydaktyczna nie jest przykrym obowiązkiem, lecz możliwością twórczego rozwijania własnych pomysłów. Tymczasem u nas ciągle pokutuje dziedzictwo PRL-u: dydaktyka jest nadal traktowana jako azyl dla nieudaczników. Myślę, że tu właśnie winien się skupić się główny wysiłek reformatorów. Tymczasem, jak dotąd, cicho. A nawet, jak już wspominałem, dydaktyka jest traktowana z lekceważeniem. Trzeba to zmienić. Nie bez powodu na najlepszych uczelniach USA pracę ze studentami traktuje się bardzo poważnie, a jej wyniki wpływają w istotny sposób na pozycję (również finansową) pracownika ${ }^{26}$.

W wypadku tworzonych od podstaw państwowych szkół zawodowych - bez historii i najczęściej lokowanych w adaptowanych obiektach powojskowych lub administracyjnych - etos niesiony przez pracowników, którzy posiadali doświadczenie akademickie, miał znaczenie pierwszorzędne, pełnił rolę wzorca i punktu odniesienia. Tym bardziej, że wielu zatrudnianych po raz pierwszy w uczelni pracowników, często nauczycieli szkół średnich, którzy nie mieli szansy by „terminować” w strukturach akademickich, nie posiadało takich doświadczeń i stosowało metody typowe dla dydaktyki szkolnej.

Sprawę utrudniało również przekonanie o prowincjonalności uczelni, często połączone z poczuciem kompleksu niższości wobec uczelni akademickich o długiej tradycji i potencjale naukowym. Utworzenie nowych, sformalizowanych organizacyjnie gremiów - działalność senatu i konwentu uczelni, wypracowanie struktur instytutów i zakładów - i realizacja ich codziennych zadań, a także organizowanie konferencji naukowych i prowadzenie badań zleconych stanowiły podstawy kształtowania kultury jakości w uczelni.

W wypadku PWSZ w Krośnie, którą historycznie poprzedziły Kolegium Nauczycielskie w Krośnie oraz Nauczycielskie Kolegia Języków Obcych w Krośnie i w Jaśle, część tego trudnego formowania została dokonana w czasie ich działalności od I99I roku, dzięki owocnej współpracy z Uniwersytetem Jagiellońskim, pracy organizacyjnej, dydaktycznej i naukowej opiekunów naukowych oraz licznej kadrze naukowo-dydaktycznej z wydziałów Filologii i Pedagogiki UJ. Podobnie zapewne było w innych uczelniach zawodowych utworzonych w oparciu o dorobek poprzedzających je kolegiów nauczycielskich lub innych szkół pomaturalnych. Nauczyciele zatrudnieni w kolegiach, zarówno miejscowi, jak z UJ i WSP w Rzeszowie, zostali zatrudnieni w PWSZ w Krośnie od pierwszego roku jej działalności. Dzięki tej formule zatrudnienia zostały spełnione wymogi prawne co do minimów kadrowych. W pierwszych latach działalności dydaktycznej większość nauczycieli była zatrudniona na tzw. drugim etacie. Wraz u upływem lat zmieniały się proporcje między nauczycielami 
zatrudnionymi w drugim miejscu pracy, a pracownikami zatrudnionymi w uczelni w podstawowym miejscu pracy. Dane zawarte w tabeli nr I ilustrują proces zmian w zatrudnieniu „własnej” kadry, z tym, że za początkowy rok przyjęto dane po zamknięciu trzeciego roku kształcenia.

Tabela 1. Zmiany struktury zatrudnienia wg stopni naukowych w PWSZ w Krośnie.

\begin{tabular}{|c|c|c|c|}
\hline $\begin{array}{l}\text { Nauczyciele zatrudnieni } \\
\text { w PWSZ w Krośnie jako pod- } \\
\text { stawowym miejscu pracy wg } \\
\text { tytułów i stopni naukowych }\end{array}$ & $\begin{array}{l}\mathbf{2 0 0 2} / \mathbf{2 0 0 3} \\
\text { stan na } \\
1.10 .2002\end{array}$ & $\begin{array}{l}\mathbf{2 0 0 8} / 2009 \\
\text { stan na } \\
1.10 .2008\end{array}$ & $\begin{array}{l}\mathbf{2 0 1 7 / 2 0 1 8} \\
\text { stan na } \\
1.10 .2017\end{array}$ \\
\hline $\begin{array}{l}\text { Profesorowie } \\
\text { i doktorzy habilitowani }\end{array}$ & $\begin{array}{l}\text { etaty }-2,0 \\
\text { osoby }-2 \\
(2-\text { pełny etat })\end{array}$ & $\begin{array}{l}\text { etaty }-1,0 \\
\text { osoby }-1 \\
(1-\text { pełny etat })\end{array}$ & $\begin{array}{l}\text { etaty }-12 \\
\text { osoby }-12 \\
(12-\text { pełny etat })\end{array}$ \\
\hline Doktorzy & $\begin{array}{l}\text { etaty }-3 \\
\text { osoby }-4 \\
(2-\text { pełny etat })\end{array}$ & $\begin{array}{l}\text { etaty }-13 \\
\text { osoby }-13 \\
(12-\text { pełny etat })\end{array}$ & $\begin{array}{l}\text { etaty }-62 \\
\text { osoby }-64 \\
(61-\text { pełny etat })\end{array}$ \\
\hline Magistrzy & $\begin{array}{l}\text { etaty }-62,5 \\
\text { osoby }-70 \\
(47-\text { pełny etat })\end{array}$ & $\begin{array}{l}\text { etaty }-73 \\
\text { osoby }-75 \\
(68-\text { pełny etat })\end{array}$ & $\begin{array}{l}\text { etaty }-53 \\
\text { osoby }-61 \\
(42-\text { pełny etat })\end{array}$ \\
\hline Ogółem: & $\begin{array}{l}68 \text { etatów, } \\
76 \text { sób, } \\
(51-\text { pełny etat })\end{array}$ & $\begin{array}{l}87 \text { etatów, } \\
89 \text { osób, } \\
\text { (81 - pełny etat) }\end{array}$ & $\begin{array}{l}127 \text { etatów, } \\
137 \text { osób, } \\
\text { (115 - pełny etat) }\end{array}$ \\
\hline \multicolumn{4}{|l|}{$\begin{array}{l}\text { Nauczyciele zatrudnieni } \\
\text { w PWSZ w Krośnie jako } \\
\text { drugim miejscu pracy }\end{array}$} \\
\hline $\begin{array}{l}\text { Profesorowie } \\
\text { i doktorzy habilitowani }\end{array}$ & $\begin{array}{l}\text { etaty }-27,0 \\
\text { osoby }-31 \\
(23-\text { pełny etat })\end{array}$ & $\begin{array}{l}\text { etaty }-41 \\
\text { osoby }-44 \\
(38-\text { pełny etat })\end{array}$ & $\begin{array}{l}\text { etaty }-30 \\
\text { osoby }-32 \\
(28-\text { pełny etat })\end{array}$ \\
\hline Doktorzy & $\begin{array}{l}\text { etaty }-34 \\
\text { osoby }-44 \\
(23-\text { pełny etat })\end{array}$ & $\begin{array}{l}\text { etaty }-57 \\
\text { osoby }-60 \\
(53-\text { pełny etat })\end{array}$ & $\begin{array}{l}\text { etaty }-16 \\
\text { osoby }-20 \\
(12-\text { pełny etat })\end{array}$ \\
\hline Magistrzy & $\begin{array}{l}\text { etaty }-31 \\
\text { osoby }-46 \\
(14-\text { pełny etat })\end{array}$ & $\begin{array}{l}\text { etaty }-23 \\
\text { osoby }-31 \\
(12-\text { pełny etat })\end{array}$ & $\begin{array}{l}\text { etaty }-8 \\
\text { osoby }-15 \\
(0-\text { pełny etat })\end{array}$ \\
\hline Ogółem: & $\begin{array}{l}92 \text { etaty, } \\
121 \text { osób, } \\
\text { ( } 60 \text { - pełny etat) }\end{array}$ & $\begin{array}{l}121 \text { etatów, } \\
135 \text { osób, } \\
\text { (103 - pełny etat) }\end{array}$ & $\begin{array}{l}54 \text { etaty, } \\
67 \text { osób, } \\
\text { (40 - pełny etat) }\end{array}$ \\
\hline Ogółem wszystkich: & $\begin{array}{l}159 \text { etatów, } \\
197 \text { osób, } \\
\text { (111 - pełny etat) }\end{array}$ & $\begin{array}{l}208 \text { etatów, } \\
224 \text { osoby, } \\
\text { (184 - pełny etat) }\end{array}$ & $\begin{array}{l}181 \text { etatów, } \\
204 \text { osoby, } \\
\text { (155 - pełny etat) }\end{array}$ \\
\hline
\end{tabular}


Dane zawarte w tabeli nr I bardzo szczegółowo ilustrują zmiany struktury zatrudnienia związane z pierwszym i drugim miejscem pracy w PWSZ w Krośnie, a także dynamikę wzrostu zatrudnienia w pierwszym miejscu pracy, przy koniecznym wyjaśnieniu, że zwiększenie zatrudnienia osób ze stopniem doktora od 4 do $64 \mathrm{w}$ ciągu i8 lat działalności uczelni jest związane z uzyskaniem takiego awansu naukowego przez pracowników uczelni, bądź zatrudnienia nauczycieli z doktoratem. Ten wzrost jest bardzo istotny, ponieważ zwiększa potencjał naukowy i dydaktyczny uczelni i sprzyja powstawaniu środowiska naukowego w Krośnie. Pozwala także przypuszczać, że przynajmniej niektórzy nauczyciele podejmą wysiłek dalszego rozwoju naukowego. Natomiast wzrost, od 2 do I2 osób, w grupie samodzielnych pracowników nauki, jest związany z uzyskaniem praw emerytalnych w macierzystej uczelni akademickiej i podjęciem zatrudnienia w PWSZ w Krośnie. Oczywistym jest również wniosek, że integrowanie społeczności pracowników naukowo-dydaktycznych zatrudnionych w uczelni jako podstawowym miejscu pracy będzie procesem długotrwałym, warunkowanym czasem koniecznym do zdobycia dorobku naukowego wymaganego do uzyskania stopni naukowych. Jest on również zależny od poprawienia warunków wynagradzania w uczelni, zabiegającej o nowych pracowników, przy często atrakcyjniejszych warunkach finansowych zatrudnienia oferowanych poza uczelnią. Należy jednak mieć nadzieję, że siła kultury akademickiej pozwoli rozwijać społeczność zarówno naukowo, jak i liczebnie, tak, aby kształtować atrakcyjną ofertę dydaktyczną uczelni, zapewniać wysoką jakość kształcenia i dbać o kulturę jakości.

W literaturze i międzynarodowych projektach badawczych kulturze jakości przypisuje się szeroki zakres, definiując ją jako kulturę organizacyjna, która sprzyja rozwojowi skutecznych i efektywnych podejść do zarzadzania jakościa i pozwala instytucjom ksztatcenia wyższego osiagać zatożone cele i wzmacniać jakość ustug edukacyjnych ${ }^{27}$. Wśród najważniejszych czynników kształtujących kulturę jakości Ł. Sułkowski wymienia m.in.:

- tworzenie wspólnoty uniwersyteckiej i dążenie do identyfikacji pracowników z instytucją akademicką,

- rozwój partycypacji studentów we wspólnocie akademickiejes,

- zakorzenienie kultury jakości w procesach wewnętrznej komunikacji, dyskusji i rozwoju odpowiedzialności, przede wszystkim w odniesieniu do oporu wobec zmian oraz rozwoju strategii ich przezwyciężania,

- zaangażowanie wewnętrznych i zewnętrznych interesariuszy w proces zapewniania jakości ${ }^{29}$.

27 Ł. Sułkowski, Kultura akademicka. Koniec utopii?, Wydawnictwo Naukowe PWN, Warszawa 20I6, s. 7 I.

28 Procentowy udział studentów w organach kolegialnych uczelni określa ustawa Prawo o szkolnictwie wyższym z dnia 27 lipca 2005, Art.: 6r, 67, 71.

29 Por. Ł. Sułkowski, Kultura akademicka. Koniec utopii?, dz. cyt., s. 70. Z szerszego katalogu przytaczam i pokrótce omawiam tylko te czynniki, które miały istotne znaczenie dla PWSZ. 
Refleksja nad tymi czynnikami pozwala dokonywać wartościowania i oceny stopnia wdrożenia kultury jakości w omawianych uczelniach. W pierwszych latach działalności dydaktycznej uczelni zawodowych większość nauczycieli była zatrudniona w nich na drugim miejscu pracy, co - nie ograniczając ich udziału w tworzeniu wspólnoty - ograniczało jednak możliwości formalnej identyfikacji z nią, np. wskutek konieczności afiliowania dorobku naukowego w uczelni macierzystej, w której byli z niego rozliczani. Czynnikiem wpływającym na utożsamianie się z uczelnią stanowiącą dodatkowe miejsce zatrudnienia, przynajmniej dla niektórych z tych pracowników, było pełnienie funkcji promotora prac doktorskich, niepowtarzalna szansa na osobiste wdrożenie autorskich programów kształcenia oraz poczucie realizacji twórczych dydaktycznie, organizacyjnie i naukowo projektów nowoczesnych laboratoriów i udziału w programach finansowanych ze środków europejskich. W wypadku Krosna wielu pracowników naukowo-dydaktycznych uczelni akademickich angażowało się bardzo mocno w rozwój PWSZ w Krośnie, ze względu na pochodzenie z Krosna lub regionu. Podobnie zapewne było i jest w innych uczelniach zawodowych w kraju.

Czynnik dotyczący zwiększenia udziału studentów we wspólnocie akademickiej, został rozwiązany ustawowo na poziomie $20 \%$ członków w organach kolegialnych uczelni, aczkolwiek nie zawsze odpowiada on rzeczywistemu i aktywnemu uczestnictwu studentów w pracach tych gremiów. Warto natomiast podkreślić ich wysoką aktywność w pracach Samorządu Studentów, wywierającą znaczący wpływ na lokalną ofertę wydarzeń kulturalnych, sportowych i społecznych, (o czym w dalszej części opracowania).

Znacząco na kulturę jakości pracy uczelni, procesy wewnętrznej komunikacji i dyskurs na temat jakości kształcenia wpłynęło wdrożenie procedur i senackich komisji ds. jakości kształcenia oraz obowiązkowa ocena pracowników uczelni. Jednoznaczne, ale i wieloaspektowe określenie podlegających ocenie osiągnięć i aktywności dydaktycznych, naukowych i organizacyjnych ma inspirować pracowników do ich podejmowania. Arkusz oceny jest zarazem wyznacznikiem oczekiwań władz uczelni wobec pracowników.

Partycypowanie osób z otoczenia zewnętrznego w zarządzaniu państwowymi uczelniami zawodowymi określił ustawodawca, poprzez wymóg tworzenia Konwen$\mathrm{tu}^{30}$. Zaproszenie do udziału w jego pracach przedstawicieli z otoczenia samorządowego, gospodarczego, pozarządowego, a także parlamentarzystów przyczyniło się do lepszego, wzajemnego poznania, nawiązania rozmaitych form współpracy, a w kolejnych latach do świadczenia przez uczelnię usług badawczych i rozwijania kształcenia w zakresie specjalności „zamawianych” zgodnie z oczekiwaniami pracodawców ${ }^{31}$.

30 Ustawa o wyższych szkołach zawodowych z dnia 26 czerwca 1997, Art. 3I-33.

31 Przykładem tej formy współpracy było rozpoczęcie w roku akademickim 20I6/20I7 kształcenia w zakresie specjalności Projektowanie i wytwarzanie w środowisku wirtualnym wspólnie z Grupą Nowy Styl i IBS Poland. 


\section{Państwowa Wyższa Szkota Zawodowa im. Stanistawa Pigonia w Krośnie}

Przyjęcie przez instytucję imienia zawsze wpisuje jej społeczność w kontekst wartości reprezentowanych przez postać patrona i symbolicznie dookreśla jej misję.

W wypadku PWSZ senaty uczelni, podejmując decyzję o przyjęciu imienia, nawiązywały najczęściej do postaci związanych bezpośrednio z miejscem ich funkcjonowania ${ }^{32}$, pięć przyjęło nazwy własne nawiązujące do ich lokalizacji lub profilu kształcenia ${ }^{33}$, a PWSZ w Białej Podlaskiej - imię Papieża Jana Pawła II. Przyjęcie przez uczelnię imienia było wyrazem woli nawiązania do wartości utożsamianych z daną postacią i zobowiązaniem do upowszechniania wiedzy o niej. Konsekwencją tych decyzji były liczne konferencje naukowe, publikacje lub inne cykliczne wydarzenia ${ }^{34}$.

Senat PWSZ w Krośnie, na wniosek jej rektora, prof. dra hab. Janusza Gruchały, przyjął uchwałę o rozpoczęciu procedury nadania uczelni imienia Stanisława Pigonia - historyka literatury polskiej, edytora i pisarza - rektora Uniwersytetu w Wilnie, profesora Uniwersytetu Jagiellońskiego - pochodzącego z Komborni, miejscowości położonej w odległości kilkunastu kilometrów od Krosna ${ }^{35}$. Wybór patrona uczelni był jednym z najważniejszych czynników dopełniania procesu kształtowania etosu uczelni. Stanisław Pigoń, wybitny uczony, niezłomny autorytet moralny w wielu miejscach, rolach i wyborach życiowych, jakie przyszło mu pełnić i podejmować w szkole, na uniwersytecie, na polu walki za ojczyznę - dopełnia i uszczegóławia, może zbyt godnie jej misję. Intencją Senatu uczelni było upamiętnienie uczonego, ale i przywoływanie wzorów:

- patriotyzmu realizowanego poprzez udział w walce zbrojnej w okresie I wojny światowej w armii austriackiej, w której uzyskał stopień porucznika, a od połowy listopada I9I8 do końca sierpnia I9I9 w wojsku polskim, z którym uczestniczył w walkach o Lwów, Przemyśl i na Śląsku. Wziął również udział, jako ochotnik, od 20 maja do I3 listopada I920 roku, w wojnie polsko-bolszewickiej jako dowódca pociągu pancernego „Bartosz Głowacki”. Kiedy Niemcy zaatakowali Polskę, rozpoczynając II wojnę

32 Dla przykładu: w Białej Podlaskiej - Papieża Jana Pawła II, w Gnieźnie - Hipolita Cegielskiego, w Gorzowie - Jakuba z Paradyża, w Jarosławiu - ks. Bronisława Markiewicza, w Kaliszu - Prezydenta Stanisława Wojciechowskiego, w Legnicy - Vitelona, w Lesznie - Jana Amosa Komeńskiego, w Oświęcimiu - rtm. Witolda Pileckiego, w Pile - Stanisława Staszica, w Sanoku - Jana Grodka, w Suwałkach - Stanisława Staszica, w Tarnobrzegu - prof. Stanisława Tarnowskiego, w Wałbrzychu - Angelusa Silesiusa, w Zamościu - Szymona Szymonowica.

33 Państwowa Wyższa Szkoła Techniczno-Ekonomiczna im. ks. Bronisława Markiewicza w Jarosławiu, Karkonoska Państwowa Szkoła Wyższa w Jeleniej Górze, Państwowa Wyższa Szkoła Informatyki i Przedsiębiorczości w Łomży, Podhalańska Państwowa Wyższa Szkoła Zawodowa w Nowym Targu, Państwowa Medyczna Wyższa Szkoła Zawodowa w Opolu, Państwowa Wyższa Szkoła Wschodnioeuropejska w Przemyślu.

34 PWSZ w Oświęcimiu rokrocznie organizuje Bieg imienia rtm. Witolda Pileckiego.

35 Na wniosek Senatu uczelni Minister Nauki i Szkolnictwa Wyższego, Barbara Kudrycka, rozporządzeniem z dnia I2 lipca 2012 roku nadała jej nazwę Państwowa Wyższa Szkoła Zawodowa im. Stanistawa Pigonia w Krośnie. Dz.U. nr 55 r. poz. 575, Warszawa, dnia 24 lipca 2012. 
światową, Profesor opuścił Kraków z synem Andrzejem, aby wstąpić do polskiego wojska, co się nie udało wskutek wrześniowej klęski. Z innym wymiarem patriotyzmu Profesora łączy się postawa w czasie zamknięcia w obozie koncentracyjnym w Sachsenhausen, a po zwolnieniu z niego organizacja i udział w tajnym nauczaniu Uniwersytetu Jagiellońskiego ${ }^{36}$,

- uczonego i edytora, jednego z najwybitniejszych badaczy twórczości Adama Mickiewicza, a także Juliusza Słowackiego, Aleksandra Fredry, Stefana Żeromskiego oraz pisarzy ludowych. Stanisław Pigoń, uczeń Ignacego Chrzanowskiego, łączył skrupulatność badacza z poczuciem odpowiedzialności za moralną wartość historii literatury. Dorobek naukowy, jak i zaangażowanie badawcze uczonego najtrafniej określił Czesław Kłak, jako wprost niestychanie rozwinięte poczucie odpowiedzialności za losy nauki w obrębie filologii polskiej ${ }^{37}$,

- społecznika, nauczyciela i wychowawcy, spolegliwego opiekuna studenckich kół i stowarzyszeń w Poznaniu, Wilnie i Krakowie, mianowanego przez Senat UJ kuratora Bratniej Pomocy Studentów Uniwersytetu Jagiellońskiego, społecznika głoszącego wykłady o tematyce historycznej i literackiej38. Ten typ perfekcyjnej pracy, bez rachuby na wielkie korzyści majątkowe, pracy podejmowanej nie przez wzglad na wtasna osobe, lecz na pożytek innym, wykonywanej w poczuciu obowiazku i dla zadoścuczynienia temu co nam powierzone... ale takíe powaga wobec życia, wytrwatość $i$ dzielność cechuja tego syna kmiecego... ${ }^{39}$. W dorobku uczonego rzecza najbardziej trwata jest być może nie zawartość publikacji, choćby najznakomitsza, lecz to, co bezpośrednio dane uczniom, wiedza i dobro. Wiedza i budujacy przyktad moralny - taki byt Pigoniowy siew na wiecznośćc $c^{\circ}$.

Równie ważna była apoteoza podkrośnieńskiej wsi Kombornia, której poświęcił tom wspomnień $Z$ Komborni w świat, podkreślając przywiązanie do „małej ojczyzny”, związki z rodzinną miejscowością i wagę wartości, jakie zaczerpnął z jej społeczności i kultury ${ }^{41}$. Owo emocjonalne nacechowanie przywiązania do miejsca urodzenia i pochodzenia, do „progu” rodzinnego, wiejskiego domu, do „kraju lat dziecinnych” w czasie europejskich i światowych migracji absolwentów uczelni w pogoni za pracą i bardziej dostatnim życiem, w czasie rozmywania tożsamości i relatywizowania wartości narodowych, posiada rangę wartości przetrwania.

Kulturotwórcze znaczenie, obok popularyzowania etosu i wartości związanych z jego działalnością i osiągnięciami, ma również działalność naukowa pracowników uczelni oraz istotne dla środowiska inicjatywy naukowe związane z postacią

36 Zob. F. Ziejka, Profesor z Komborni, [w:] tenże, Mistrzowie stowa i czynu, Kraków 20II, s. 3IO-3II.

37 C. Kłak, Pigoń, Wydawnictwo Uniwersytetu Rzeszowskiego, Rzeszów 2or3, s. I3.

38 Por. F. Ziejka, Stanistaw Pigoń mniej znany, [w:] tenże, Mistrzowie stowa i czynu, dz. cyt., s.317-339.

39 B. Dopart, Stanistaw Pigoń-pisarz, [w:] Ziemia krośnieńska w kulturze polskiej, red. H. Kurek i F. Tereszkiewicz, Kraków 1996, s. 78.

40 B. Dopart, Stanistaw Pigoń - pisarz, [w:] Inteligencja potudniowo-wschodnich ziem polskich, red. H. Kurek i F. Tereszkiewicz, Kraków 1998, s. I40.

41 Por. F. Ziejka, Mate ojczyzny Stanistawa Pigonia, [w:] tenże, Mistrzowie stowa i czynu, dz. cyt., s. $345-350$. 
Patrona uczelni. Za najważniejszą należy uznać zorganizowaną wspólnie z UJ i WSP w Rzeszowie rocznicową konferencję ${ }^{42}$. Część okolicznościowych obchodów odbyła się w Komborni, gdzie, w dniu I4 listopada 2008 roku, Franciszek Ziejka wygłosił wykład Stanistaw Pigoń - profesor z Komborni. Ważne dla społeczności uczelni były również otwarte wykłady i okolicznościowe wydawnictwa uczelniane - Franciszek Ziejka, Mate ojczyzny Stanistawa Pigonia, Krosno 2006 i Tata Pigoń. Kartka z dziejów tajnego uniwersytetu $w$ Krakowie, wstęp Janusz S. Gruchała, Krosno 2008. Innym, równie interesującym, ludycznym sposobem upowszechniania wiedzy o postaci Stanisława Pigonia była inicjatywa zorganizowania w Komborni Pikniku u Pigonia, wydarzenia obejmującego grę terenową, dyktando i warsztaty literackie dla uczniów szkół. Piknik został zaplanowany i zorganizowany przez pracowników i studentów uczelni, a organizacyjnej pomocy udzielił dyrektor i nauczyciele szkoły podstawowej w Komborni oraz wójt Gminy Korczyna. Piknik, zorganizowany po raz pierwszy w 2017 roku, został zaprojektowany jako wydarzenie cykliczne.

Unikatowym, możliwym dzięki szczęśliwemu zbiegowi okoliczności ${ }^{43}$, sposobem zachowania materialnych reliktów dzieciństwa Stanisława Pigonia było zakupienie przez uczelnię położonego w Komborni jego domu rodzinnego z zachowaną, wybudowaną przez Profesora przybudówką, w której spędzał wakacje. Zaplanowano renowację i modernizację z przeznaczeniem na Dom Pamięci Profesora, a zarazem niewielkie muzeum podkarpackiej kultury ludowej. Szczęśliwie zachowała się również część wyposażenia: meble, część sprzętu gospodarczego, skrzynie, a także stodoła i koło kieratu. W formie darowizny uczelnia otrzymała miech kowalski, z którego korzystał ojciec Profesora. Ponadto uczelnia otrzymała, również w formie darowizny, działki rolne położone w bezpośrednim sąsiedztwie domu. Dwie o powierzchni 90 arów z zasobów Agencji Nieruchomości Rolnych Skarbu Państwa ${ }^{44}$ i jedną o powierzchni 30 arów z zasobów Gminy Korczyna ${ }^{45}$. Całość areału została zrekultywowana z przeznaczeniem na uprawy i miejsce praktyk terenowych dla studentów kierunków: Produkcja i bezpieczeństwo żywności i Zielarstwo. Poddano pielęgnacji zachowane drzewa owocowe w sadzie oraz zasadzono dawne gatunki roślin uprawnych. Zakupione zostały również pnie pszczele do pasieki. Po zakończeniu remontu domu i zagospodarowaniu nieruchomości zostanie odtworzone założenie małoareałowego gospodarstwa rolnego, typowego dla tej części Podkarpacia w pierwszej połowie XX wieku.

42 Teksty wygłoszone w czasie konferencji zebrano w tomie. Profesor z Komborni. Stanistaw Pigoń, w czterdziestą rocznicę śmierci, red. F. Ziejka, C. Kłak, J. Gruchała, K. Fiołek, Wydawnictwo Uniwersytetu Jagiellońskiego, Kraków 2010.

43 Informację o zamiarze sprzedania domu rodzinnego Stanisłąwa Pigonia przez spadkobierców przekazała do PWSZ w Krośnie A. Winiarska, absolwentka Kolegium Nauczycielskiego w Krośnie, autorka i wydawca książki: Stanistaw Pigoń - syn Komborni, Krosno 2008.

44 Działki nr: 439/r i 439/5 położone w Komborni, gmina Korczyna.

45 Działka nr 439/2 położona w Komborni, gmina Korczyna. 


\section{Ksztattowanie oferty dydaktycznej}

W osiągnięcia i kulturotwórczą rolę państwowych wyższych szkół zawodowych wpisuje się najważniejsze z ich zadań, tj. działalność dydaktyczna, umożliwiająca studentom zdobywanie wiedzy, umiejętności i kompetencji społecznych. W pierwszym okresie działalności mogły one prowadzić studia w ramach specjalności - po spełnieniu warunków co do minimum kadrowego w wymiarze - jeden samodzielny pracownik naukowy i dwóch ze stopniem doktora w danej specjalności. Pozytywnie wartościując takie rozwiązanie dydaktyczne, T. Winnicki, pierwszy rektor PWSZ w Jeleniej Górze (Kolegium Karkonoskie) argumentował: Specjalność, która można dość tatwo zatożyć, wobec znacznie nizszych wymagań kadrowych, pozwala szybko reagować na dynamicznie zmieniajace się zapotrzebowanie lokalnego rynku pracy, którego zaspokojenie byto drugim, obok samego umożliwienia edukacji wyższej, celem pomystodawców tego typu szkót ${ }^{46}$. Wykorzystując tę możliwość tworzono, po analizie lokalnego rynku pracy, w uczelniach nowatorskie, unikatowe specjalności kształcenia, często we współpracy w miejscowymi pracodawcami i władzami samorządowymi.

W 2005 roku ustawowo nałożono na uczelnie obowiązek przyporządkowania specjalności do kierunków studiów ${ }^{47}$. Jednak praktyka kształcenia w ramach specjalności dostosowanych do lokalnych warunków, choćby ze względu na niewielką mobilność studentów, a także oczekiwania i chęć współpracy (nawet finansowania części kosztów kształcenia przez pracodawców) obowiązuje w większości PWSZ także obecnie. Tym bardziej, że utworzenie specjalności kształcenia w ramach kierunku studiów może być podjęte przez uczelnię, bez wnioskowania o opinię PKA, pod warunkiem spełnienia wymogu zapewnienia odpowiedniej kadry naukowo-dydaktycznej (jeden samodzielny pracownik i dwóch pracowników ze stopniem doktora) dla specjalności. Dzięki temu uczelnie zawodowe mogą łatwo dostosowywać ofertę dydaktyczną do oczekiwań pracodawców. Dla przykładu, w PWSZ w Krośnie utworzone zostały studia na następujących specjalnościach: mechanika lotnicza (2008), produkcja i bezpieczeństwo żywności (2015), projektowanie i wytwarzanie w środowisku wirtualnym (2016), bezpieczeństwo sieci informatycznych (20I7).

Większość PWSZ organizuje również studia podyplomowe, odpowiadające zapotrzebowaniu lokalnemu. Część z nich została sfinansowana ze środków Europejskiego Funduszu Społecznego w ramach projektów europejskich. Z możliwości uzupełnienia wykształcenia, bez ponoszenia kosztów, skorzystało wiele osób zatrudnionych w gospodarce. Ponadto wiele uczelni oferuje pełnopłatne studia podyplomowe, z których korzysta wiele osób uzupełniających wykształcenie lub zdobywających nowe kwalifikacje. W takiej formule finansowej w PWSZ w Krośnie zorganizowano studia w zakresie: polonistyki (2000/200I), nauczania zintegrowanego w praktyce szkolnej (200o/200I), nauczania zintegrowanego w praktyce szkolnej i w wycho-

46 T. Winnicki, Ciężki poród i trudne dzieciństwo Państwowych Wyższych Szkót Zawodowych. Impresje nieinstytucjonalne, [w:] Udana dekada..., dz. cyt., s. 32.

47 Ustawa z dnia 5 stycznia 2005, Dz. U. 2005, nr 23, poz. 187. 
waniu przedszkolnym (200o/200I), audytu energetycznego na potrzeby termomodernizacji i certyfikacji energetycznej w budownictwie (2008/2009, 2009/2010), przygotowania pedagogicznego (2016/2017, 20I7/2018), towaroznawstwa zielarskiego, kosmetycznego i żywności funkcjonalnej (2013/20I4, 20I4/20I5, 20I7/20I8), bezpieczeństwa systemów informacyjnych (2017/2018), rolnictwa (2017/2018).

Oprócz studiów pierwszego stopnia, większość publicznych uczelni zawodowych (20) otworzyła studia magisterskie. Tworzenie studiów II stopnia w uczelniach zawodowych było i jest przedmiotem wielu krytycznych uwag i zastrzeżeń związanych z brakiem własnej kadry i zatrudnianiu, w związku z tym, pracowników na drugim etacie lub wyłącznie emerytów. Zastrzeżenia co do jakości kształcenia dotyczą również braku odpowiednio wyposażonych bibliotek i infrastruktury. Minister Nauki i Szkolnictwa Wyższego Jarosław Gowin w okresie konsultacji projektów i proponowanych zapisów ustawy 2.0 ze środowiskami akademickimi podkreślał wielokrotnie, że publiczne uczelnie zawodowe powinny prowadzić studia pierwszego stopnia o profilu praktycznym. Stanowisko ministra wprost koresponduje z przytoczonymi, w zarysie, na początku niniejszego tekstu celami amerykańskiego szkolnictwa wyższego.

\section{Praktyczny profil ksztatcenia}

Podstawowym celem działalności uczelni wyższej jest wykształcenie wysoko wykwalifikowanych absolwentów, dobrze przygotowanych do podejmowania pracy zawodowej. Nowa formuła kształcenia wprowadzona Rozporządzeniem Ministra Nauki i Szkolnictwa Wyższego nakłada na uczelnie wdrażające praktyczny profil kształcenia obowiązek realizowania w planie studiów ponad 50\% zajęć o charakterze praktycznym (laboratoriów, projektów i ćwiczeń) oraz minimum Is tygodni praktyk zawodowych. Notabene, wymóg realizacji Is tygodni praktyk zapisano w ustawie o wyższych szkołach zawodowych z 1997 roku. To założenie obejmuje również inne konsekwencje, np. zmianę myślenia o procesie dydaktycznym przez nauczycieli, wymuszając przygotowanie i opracowanie na nowo kart przedmiotów, a przede wszystkim wprowadzenie praktycznych treści kształcenia, umożliwiających wykorzystanie wiedzy i jej praktyczne zastosowanie. O znaczeniu tych rozwiązań prawnych i praktyce dydaktycznej w następujący sposób pisał J. Draus:

Podkreślić należy, że dla absolwentów studiów I stopnia wyższych szkół zawodowych nie ma przymusu dalszego studiowania. Powinien jednak istnieć przymus dobrego przygotowania do wykonywania określonego zawodu, a zarazem nie zamykania drogi do dalszego kształcenia. W przeciwnym razie zatraca się użytkowa wartość i autonomiczność dyplomu I stopnia studiów oraz wytwarza się sytuacja przymusu kontynuacji studiów, niezależnie od uzyskanych ocen i uzdolnień absolwenta. Prowadzi to do inflacji dyplomów, obniżenia prestiżu studiów II stopnia, a zarazem uniwersytetów, oraz niweczy konkurencję. Dy- 
plom I stopnia studiów powinien odzwierciedlać wiedzę i kwalifikacje zawodowe absolwenta, zaś II stopnia pogłębioną wiedzę specjalistyczną, a nie spełniać funkcję „waluty obiegowej”, za którą można kupić posadę na rynku pracy ${ }^{48}$.

Dla studentów praktyczny profil studiów oznacza nastawienie procesu dydaktycznego na kształcenie umiejętności operacyjnych - w warunkach odpowiadających środowisku przyszłej pracy absolwenta. W celu spełnienia tego wymogu należy ustawicznie modernizować wyposażenie laboratoriów, a także blisko współpracować z interesariuszami zewnętrznymi uczelni w zakresie ustalania programów kształcenia i realizacji studenckich praktyk zawodowych. Ścisłą współpracę z uczelnią w tym zakresie podjęły m.in.: Grupa Nowy Styl, Splast, szpitale w Krośnie i Brzozowie i inni. Warto podkreślić, że oczekiwania pracodawców wynikają z coraz większego zaawansowania technologicznego, bardziej złożonych maszyn i procesów produkcyjnych, wysokich kosztów ich wdrażania, a także skutków, również finansowych, błędów popełnianych przez pracowników. Powyższe wymagania wobec procesu dydaktycznego znajdują odzwierciedlenie w polityce prawnej MNiSW, dzięki czemu uczelnie mogą zaliczać do minimów kadrowych pracowników z doświadczeniem zawodowym zatrudnionych w podstawowym miejscu pracy poza uczelnią. Warto dodać, że tacy pracownicy, dzieląc się ze studentami wiedzą i doświadczeniem zawodowym, uzyskują bardzo dobre oceny za merytoryczny poziom zajęć. Studenci wysoko oceniają także możliwości odbywania części zajęć, praktyk i staży zawodowych u pracodawców ${ }^{49}$. Bardzo często po zakończeniu praktyki otrzymują ofertę pracy.

Przygotowanie uczelni wyższych do wdrożenia praktycznego profilu studiów, a także studiów dualnych będzie procesem złożonym i długotrwałym ${ }^{50}$. Dla przykładu, wdrażanie praktycznego profilu kształcenia w PWSZ w Krośnie rozpoczęto od roku akademickiego 2012/20I3, a kolejne lata przynoszą nowe problemy programowe i organizacyjne, a także ich rozwiązywania i wdrożenia do ww. procesu ${ }^{\text {sI }}$. Dobrym przykładem, pozytywnych efektów osiąganych w tym zakresie są studia na kierunku Pielęgniarstwo, zachowujące, jak się wydaje, optymalne proporcje między przedmiotami teoretycznymi, kształceniem praktycz-

48 J. Draus, Miejsce Państwowych Wyższych SzkótZawodowych w polskim systemie szkolnictwa wyższego, [w:] Udana dekada..., dz. cyt., s. 27.

49 Zorganizowanie i sfinansowanie dodatkowych praktyk i staży było możliwe dzięki realizacji projektów finansowanych z Programu Operacyjnego Wiedza Edukacja Rozwój. Program praktyk zawodowych w Państwowych Wyższych Szkołach Zawodowych, Nabór I, 20I7/20i8; Nabór III, 20I8/2019.

50 Liderem kształcenia dualnego w Polsce jest PWSZ w Lesznie. Leszczyński model tych studiów został opisany w artykule: Wielkie zmiany trzeba zaczać od siebie, [w:] Forum akademickie, 20I8, nr 5, s. 4I-43.

51 Uchwała Senatu PWSZ w Krośnie nr I/I4 z dnia 28 stycznia 2014 r. w sprawie potwierdzenia praktycznego profilu kształcenia w PWSZ im. Stanisława Pigonia w Krośnie. 
nym i samokształceniem ${ }^{52}$. Ten przykład dobrze ilustruje złożoność problemu. Wyważenie tych proporcji w odniesieniu do innych kierunków studiów będzie trudne i powinno być ustawicznie modyfikowane zgodnie z wynikami ewaluacji wyników współpracy prowadzonej wspólnie przez uczelnię i pracodawców.

Wdrożenie praktycznego profilu kształcenia w przypadku państwowych szkół zawodowych to również odpowiedź na potrzeby społeczne, która powinna być jednoznacznie wpisana misję uczelni finansowanych z budżetu państwa. Oznacza to, że studenci i absolwenci tych szkół powinni być zorientowani na potrzeby rynku pracy. I jeszcze jeden ważny aspekt związany z tym profilem kształcenia. Dodatkowym argumentem za ksztatceniem praktycznym jest to, że predyspozycje intelektualne studentów masowych często nie pozwalaja na pokonanie wyrafinowań poznawczych wtaściwych ksztatceniu akademickiemu. Pojawia się zatem konflikt pomiędzy bezinteresowna pasja badawczq a badaniem nakierowanym na cele praktycznie użyteczne - obydwa bezwzględnie konieczne w pracy uczelni ${ }^{33}$. W wypadku uczelni zawodowych ten konflikt jest mniej ostry, gdyż większość kandydatów i studentów wiąże swoją przyszłość z praktycznym wykonywaniem zawodu zgodnym z kierunkiem studiów.

\section{Studenci i absolwenci}

Najważniejszym czynnikiem kulturotwórczym PWSZ jest umożliwienie podejmowania studiów wyższych tym kandydatom, dla których w sytuacji braku tej oferty, istniały nieprzekraczalne bariery dostępu do szkół wyższych. Wśród najczęściej wymienianych barier są: problemy finansowe wynikające z kosztów utrzymania studenta w dużych ośrodkach akademickich oraz słabsze wyniki z egzaminu dojrzałości, uniemożliwiające osiągnięcie progów wymagań ustalonych przez uczelnie akademickie. Dla takich kandydatów oferta publicznych szkół zawodowych była szansą na podjęcie studiów I stopnia i zdobycie wiedzy i umiejętności umożliwiających poszukiwanie atrakcyjnej pracy zawodowej, a dla wielu absolwentów możliwość podjęcia studiów II stopnia w trybie stacjonarnym bądź niestacjonarnym, łączonym z pracą zawodową (ten wariant wybiera większość absolwentów). Oczywistym jest również, że absolwenci znacząco podnieśli współczynnik skolaryzacji, zwłaszcza wśród mieszkańców wsi i małych miast.

Zestawienie porównawcze liczb studentów i absolwentów PWSZ w Krośnie po pierwszym dziesięcioleciu i u progu dwudziestolecia działalności obrazuje wielką skalę zjawiska.

52 Aczkolwiek warto zwrócić uwagę na dużą liczbę godzin dydaktycznych zaplanowanych na tzw. godziny kontaktowe i samokształcenie, łącznie 4700 godzin, co powoduje bardzo duże obciążenie obowiązkami dla studentów tego kierunku.

53 Program rozwoju szkolnictwa wyższego do 2020 r. Część II. Misja spoteczna uniwersytetu wXXI wieku, red. A. Szostek, Warszawa 2015, s. I3. 
Tabela nr 2. Liczba studentów i absolwentów w PWSZ w Krośnie; zgodnie ze sprawozdaniem S10, wg kierunków studiów.

\begin{tabular}{|c|c|c|c|c|}
\hline $\begin{array}{l}\text { Liczba } \\
\text { studentów }\end{array}$ & Rodzaj studiów & $\begin{array}{l}\text { Liczba } \\
\text { studentów }\end{array}$ & Rodzaj studiów & $\begin{array}{l}\text { Liczba } \\
\text { studentów }\end{array}$ \\
\hline $\begin{array}{l}\text { W dziesiątym } \\
\text { roku działalności } \\
\text { 2007/2008w }\end{array}$ & $\begin{array}{l}\text { Studenci } \\
\text { stacjonarni }\end{array}$ & 2989 & $\begin{array}{l}\text { Studenci } \\
\text { niestacjonarni }\end{array}$ & 1693 \\
\hline \multicolumn{5}{|c|}{ w tym: } \\
\hline & $\begin{array}{l}\text { Studia } \\
\text { humanistyczne }{ }^{54}\end{array}$ & 984 & $\begin{array}{l}\text { Studia } \\
\text { humanistyczne }\end{array}$ & 430 \\
\hline & $\begin{array}{l}\text { Pielęgniarstwo, } \\
\text { Turystyka i rekreacja, } \\
\text { Wychowanie fizyczne, } \\
\text { Zarządzanie }\end{array}$ & 1272 & $\begin{array}{l}\text { Pielęgniarstwo, } \\
\text { Turystyka i rekreacja, } \\
\text { Wychowanie fizyczne, } \\
\text { Zarządzanie }\end{array}$ & 425 \\
\hline & Studia inżynierskie & 733 & Studia inżynierskie & 838 \\
\hline $\begin{array}{l}\text { W roku akademic- } \\
\text { kim 2017/2018 }\end{array}$ & $\begin{array}{l}\text { Studenci } \\
\text { stacjonarni }\end{array}$ & 1786 & $\begin{array}{l}\text { Studenci } \\
\text { niestacjonarni }\end{array}$ & 432 \\
\hline \multicolumn{5}{|c|}{ w tym: } \\
\hline & $\begin{array}{l}\text { Studia } \\
\text { humanistyczne }\end{array}$ & 390 & $\begin{array}{l}\text { Studia } \\
\text { humanistyczne }\end{array}$ & 0 \\
\hline & $\begin{array}{l}\text { Pielęgniarstwo, Tu- } \\
\text { rystyka i rekreacja, } \\
\text { Wychowanie fizyczne, } \\
\text { Zarządzanie }\end{array}$ & 614 & $\begin{array}{l}\text { Pielęgniarstwo, } \\
\text { Turystyka i rekreacja, } \\
\text { Wychowanie fizyczne, } \\
\text { Zarządzanie }\end{array}$ & 69 \\
\hline & Studia inżynierskie & 782 & Studia inżynierskie & 363 \\
\hline \multicolumn{5}{|c|}{ LICZBA ABSOLWENTÓW } \\
\hline $\begin{array}{l}\text { Po dziesięciu } \\
\text { latach działalności } \\
2008 / 2009\end{array}$ & Studia stacjonarne & 3944 & Studia niestacjonarne & 2051 \\
\hline \multicolumn{5}{|l|}{ w tym: } \\
\hline & $\begin{array}{l}\text { Studia } \\
\text { humanistyczne }\end{array}$ & 1289 & $\begin{array}{l}\text { Studia } \\
\text { humanistyczne }\end{array}$ & 298 \\
\hline & $\begin{array}{l}\text { Pielęgniarstwo, } \\
\text { Turystyka i rekreacja, } \\
\text { Wychowanie fizyczne, } \\
\text { Zarządzanie }\end{array}$ & 1147 & $\begin{array}{l}\text { Pielęgniarstwo, } \\
\text { Turystyka i rekreacja, } \\
\text { Wychowanie fizyczne, } \\
\text { Zarządzanie }\end{array}$ & 757 \\
\hline & Studia inżynierskie & 1508 & Studia inżynierskie & 996 \\
\hline
\end{tabular}

54 Do studiów humanistycznych zaliczono studentów: Filologii (angielskiej, germańskiej i rosyjskiej), Filologii polskiej, Pedagogiki. 
Kulturotwórcza rola państwowych uczelni zawodowych. Od elitarnego do egalitarnego modelu studiów wyższych

\begin{tabular}{|l|l|l|l|l|}
\hline $\begin{array}{l}\text { Od początku dzia- } \\
\text { falności uczelni } \\
\text { do roku akademic- } \\
\text { kim 2016/2017 }\end{array}$ & Studia stacjonarne & 8341 & Studia niestacjonarne & 4253 \\
\hline \multicolumn{2}{|c|}{ w tym: } \\
\hline & $\begin{array}{l}\text { Studia } \\
\text { humanistyczne }\end{array}$ & 2744 & $\begin{array}{l}\text { Studia } \\
\text { humanistyczne }\end{array}$ & 748 \\
\hline & $\begin{array}{l}\text { Pielęgniarstwo, } \\
\text { Turystyka i rekreacja, } \\
\text { Wychowanie fizyczne, } \\
\text { Zarządzanie }\end{array}$ & 2312 & $\begin{array}{l}\text { Pielęgniarstwo, } \\
\text { Turystyka i rekreacja, } \\
\text { Wychowanie fizyczne, }\end{array}$ & 1517 \\
Zarządzanie
\end{tabular}

Dane zebrane w tabeli nr 2 ilustrują preferencje kandydatów co do wyboru kierunku studiów w pierwszym i drugim dziesięcioleciu działalności uczelni. Oprócz zmniejszenia się ogólnej liczby studentów, nastąpiło zmniejszenie liczby studentów studiów humanistycznych, przy niewielkim wzroście liczby studentów studiów inżynierskich. Studia w PWSZ Krośnie w pierwszym dziesięcioleciu ukończyło 5995 osób, a do końca roku akademickiego 20I6/20I7 I2 594 osoby. W całym kraju wszystkie publiczne do końca roku akademickiego 2016/2017 uczelnie ukończyło 294 09I osób.

Dane dotyczące liczby studentów w dziesiątym roku (2007/2008) działalności zebrał Janusz Gruchała:

Liczba studentów w roku akademickim 2007/2008 we wszystkich PWSZ wyniosła około 99500, w tym na studiach niestacjonarnych było około 50800 osób. W porównaniu z danymi z lat ubiegłych odnotowano więc niewielki spadek, przy czym dotyczył on tylko płatnych studiów niestacjonarnych, na które od 2007 r. uczelnie publiczne nie otrzymują nawet częściowej dotacji dydaktycznej. Średnio publiczna wyższa szkoła zawodowa w Polsce liczy 2843 studentów. Największą pod tym względem uczelnią jest PWSZ w Legnicy (7940 studentów), najmniejsze zaś szkoły liczą po kilkuset słuchaczy: niedawno utworzona PWSZ w Sandomierzu ıoo, w Suwałkach studiuje 4I7, a w Wałczu 457 osób. Daje się zaobserwować pewna prawidłowość: najdawniej utworzone szkoły okrzepły po kilku latach i kształcą dziś po co najmniej 3000 osób 55 .

W dwudziestym roku działalności (20I7/20I8) we wszystkich PWSZ studiuje około 5I 860 osób, w tym na studiach stacjonarnych 4I 600. W ciągu minionego dziesięciolecia nastąpił spadek liczby studentów o blisko 50\%. Ważne są jednak proporcje; na studiach stacjonarnych zmniejszenie wyniosło ok. $15 \%$, a na niestacjonarnych ok. $80 \%$. Średnio państwa wyższa szkoła zawodowa liczy ok. 1525 studentów. Nastąpiła również zmiana na pozycji ,lidera” - w roku dwudziestolecia najwięcej osób, tj. 3963 ,

55 J.S. Gruchała, Dzień dzisiejszy publicznych szkót zawodowych w Polsce, [w:] Udana dekada..., dz. cyt., s. 37 . 
studiuje w PWSZ w Tarnowie. Zmniejszenie liczby studentów należy tłumaczyć sytuacją demograficzną w Polsce, a także zmniejszeniem zainteresowania podejmowaniem studiów, zwłaszcza niestacjonarnych. W tej sytuacji za korzystne należy uznać nieznaczne (I5\%) zmniejszenie się liczby studentów na studiach stacjonarnych, co świadczy o tym, że publiczne uczelnie zawodowe dobrze wpisały się w lokalną ofertę studiów, a także o tym, że maturzyści zamieszkujące małe miasta i wsie chętniej niż mieszkańcy metropolii podejmują studia wyższe. Z zastrzeżeniem, że ta teza wymaga potwierdzenia bardziej szczegółowymi danymi statystycznymi.

Nastąpiły również zmiany strukturalne, PWSZ w Sulechowie została przekształcona w jednostkę Uniwersytetu Zielonogórskiego, a PWSZ w Sandomierzu w jednostkę zamiejscową Uniwersytetu Jana Kochanowskiego w Kielcach. PWSZ w Gorzowie uchwałą Sejmu RP została przekształcona w Akademię im. Jana z Paradyża. W wyniku tych zmian w roku akademickim 20I7/20I8 w kraju prowadzą działalność 34 państwowe wyższe szkoły zawodowe.

\section{Studia za granica}

Warunki dla rozwoju współpracy krajowych uczelni z zagranicznymi partnerami, obejmujące semestralne studia w uczelniach europejskich, realizację praktyk zawodowych przez studentów oraz staże naukowo-dydaktyczne dla pracowników powstały po przyjęciu Polski do Unii Europejskiej. Do programu Erasmus przystąpiły niemal wszystkie PWSZ, nawiązując współpracę z uczelniami wyższymi w wielu krajach Europy $^{56}$. PWSZ w Krośnie współpracę międzynarodową rozpoczęła od umów z uczelniami na Węgrzech, tj. Kolegium im. Jana Comeniusa w Sárospatak oraz Uniwersytetami w Miszkolcu i Piliscsabie. W oparciu o podpisane umowy rozpoczęto wymianę studentów i pracowników, organizację zajęć warsztatowych i praktyk, realizację projektów europejskich oraz podejmowanie wspólnych wydarzeń kulturalnych i sportowych. Jednak większe możliwości studiowania w uczelniach zagranicznych pojawiły się wraz z objęciem studentów PWSZ programem Erasmus, do którego PWSZ w Krośnie przystąpiła w 2007 roku.

W latach 2007-20I3 PWSZ w Krośnie zawarła umowy o współpracy z ponad trzydziestoma uczelniami z Niemiec, Francji, Włoch, Hiszpanii, Wielkiej Brytanii, Turcji, Rumunii, Słowenii, Szwecji, Grecji, Portugalii, Austrii, Norwegii i Holandii. Dzięki finansowaniu uzyskanemu z tego programu liczba wysyłanych i przyjmowanych studentów i wykładowców wzrosła kilkakrotnie. W ciągu sześciu lat ponad 200 studentów naszej uczelni otrzymało dofinansowanie studiów za granicą. Polacy najchętniej wybierają uczelnie hiszpańskie i niemieckie, a do Krosna najczęściej przyjeżdżają uczniowie z Turcji, Hiszpanii, Grecji i Portugalii. Tak intensywna wy-

56 Od 2005 roku Kartę Erasmusa posiada PWSZ w Elblągu i współpracuje z uczelniami w Niemczech, na Litwie, Łotwie i w Rosji (Kaliningrad), a owocną współpracę z uczelniami niemieckimi realizuje PWSZ w Legnicy. W dużym stopniu o rozwoju współpracy decydowało przygraniczne położenie uczelni. 
miana czyni uczelnię krośnieńską miejscem prawdziwie międzynarodowym. Jako jedyna państwowa uczelnia zawodowa w Polsce PWSZ w Krośnie koordynowała w latach 20IO-20I2 projekt Erasmus Intensive Programme pod nazwą „Migration and Narration". Przez trzy lata w murach uczelni spotykali się wykładowcy i studenci z Niemiec, Hiszpanii, Wielkiej Brytanii, Węgier, Danii, Szwecji, Ukrainy, Stanów Zjednoczonych i Polski, by dyskutować o roli migracji w dzisiejszej kulturze. W intensywnym kursie letnim wzięło udział ponad Ioo studentów z zagranicy, a wyniki badań przeprowadzonych na potrzeby kursów oferowanych w programie zostały opublikowane w dwóch tomach zbiorowych: Migration, Narration, Communication: Cultural Exchanges in a Globalised World (red. A. Witalisz, Frankfurt: Peter Lang 20II) oraz Migration, Narration, Identity: Cross-Cultural Perspectives (red. P. Leese, C. McLaughlin, W. Witalisz, Frankfurt: Peter Lang 20I2) ${ }^{57}$.

W kolejnych latach (20I4-20I8) poszerzono zakres współpracy o kolejne uczelnie w UE, a także w Rosji (Filia Rosyjskiego Uniwersytetu Humanistycznego w Domodiedowo, Państwowy Uralski Uniwersytet Pedagogiczny w Jekaterynburgu), na Ukrainie (Uniwersytet Lwowski, Akademia Drukarstwa we Lwowie) i w Kazachstanie (Uniwersytet Suleymana Demirela, Ałmaty).

Bardzo owocne okazały się porozumienia z uczelniami w USA, w ramach których odbywa się bezkosztowa wymiana studentów. Umowy cenne, tym bardziej, że Podkarpacie było regionem, z którego następowała intensywna emigracja zarobkowa od drugiej połowy XIX wieku. Mogli zatem studenci korzystający z wymiany poznać również środowiska polonijne w Ameryce. Umowy zawarto z University of Northern Iowa, Westfield State University (Massachusetts) oraz Simpson College (Iowa), a następnie East Carolina University, dzięki, której PWSZ w Krośnie została w 2oII roku członkiem Global Partners in Education - sieci ponad 80 uczelni z całego świata promujących nauczanie na odległość. Realizując „sieciową” współpracę studenci odbywają regularnie międzyuczelniane zajęcia dydaktyczne korzystając z platformy Global Understanding.

Nie do przecenienia jest kulturotwórcze znaczenie studiowania w uczelniach za granicą. Oprócz efektów dydaktycznych studia te umożliwiają doskonalenie języków obcych, poznawanie geografii, historii, kultury i obyczajów, a także problemów, z jakimi muszą sobie radzić mieszkańcy innych krajów. Sprzyjają one również nawiązywaniu znajomości i przyjaźni między młodymi ludźmi, co sprzyja lepszemu rozumieniu innych kultur.

Oprócz studiów, praktyk i staży studentów i nauczycieli, współpraca z uczelniami zagranicznymi pozwoliła rozwinąć w Krośnie inne atrakcyjne formy współdziałania, jak: konferencje naukowe, warsztaty wakacyjne, transgraniczne projekty europejskie ${ }^{58}$

57 Państwowa Wyższa Szkota Zawodowa imienia Stanistawa Pigonia w Krośnie 1999-2014, red. J. Jagiełło-Kuczała, J. Kułakowska-Lis, F. Tereszkiewicz, Krosno 20I4, s. 90-92.

58 Projekty realizowane w ramach Programu Współpracy Transgranicznej Polska-Białoruś-Ukraina 2007-20I3: I. Geo-Karpaty - utworzenie polsko-ukraińskiego szlaku turystycznego, okres realizacji od I.04.2012 do 31.08.2014. 2. Kształtowanie postaw prozdrowotnych wśród młodzieży na obszarze polsko-ukraińskiego pogranicza, okres realizacji od I.OI.2OI4 do 3I.I2.20I4. Projekty realizowane w ramach Programu Współpracy Transgranicznej Rzeczpospolita Polska- 
czy wspieranie rozwoju nowych specjalności kształcenia ${ }^{59}$. Bardzo ważnym transgranicznym wydarzeniem stał się Międzynarodowy Festiwal Młodzieży, organizowany rokrocznie od 2008 roku. W ostatnich kilku latach formuła festiwalu została znacząco rozwinięta i w pełni odpowiada hasłu Od Atlantyku po Ural ${ }^{60}$.

\section{Dziatalność Samorządu Studentów}

Utworzenie uczelni w naturalny, zgodny z tradycją i prawem, sposób zapoczątkowało rozwój samorządności studenckiej. Debiutujący w działalności samorządowej studenci otrzymali wsparcie władz uczelni w osobach opiekunów samorządu oraz Parlamentu Studentów. Dzięki temu bardzo sprawnie włączyli się w prace wszystkich organów kolegialnych uczelni oraz zaangażowali się w różne formy działalności kulturalnej. Pierwsze lata działalności samorządu upłynęły na gromadzeniu niezbędnych doświadczeń i liczebnym rozwoju środowiska, lecz w kolejnych można było podziwiać entuzjazm i wielość inicjatyw studenckich. Do rangi sztandarowej imprezy studenckiej zaliczano oczywiście Juwenalia, ale także inicjatywy konkursów artystycznych: literackich, filmowych i fotograficznych oraz imprezy turystyczne i sportowe. Podkreślenia warta jest studencka aktywność społeczna w zakresie krwiodawstwa i wolontariat, rozwijana niemal wyłącznie z inicjatywy studentów, którzy w uczelni często kontynuowali i rozwijali pasje zapoczątkowane w czasie nauki w szkołach ponadgimnazjalnych.

Opis aktywności studentów byłby niepełny bez uzupełnienia go o działalność studenckich kół naukowych. Źródłem inspiracji byli najczęściej pracownicy uczelni, lecz bez studenckiego zaangażowania, chęci poszerzania wiedzy i terminowania „W nauce” inicjatywy te nie mogłyby zostać zrealizowane z pozytywnym skutkiem. Członkowie kół naukowych angażują się ponadto w organizację Nocy nauki, obsługę konferencji naukowych organizowanych przez uczelnię, olimpiad i konkursów wiedzy, warsztatów dla uczniów szkół i inne formy popularyzowania studiów. Wielość i rozmaitość studenckich inicjatyw i wydarzeń zasługuje na oddzielne opracowanie, gdyż stanowi ona bardzo dobry przykład aktywności, twórczych zainteresowań i społecznej wrażliwości studentów ${ }^{61}$. Warto zwrócić uwagę na jeszcze jeden

Republika Słowacka 2007-2013: I. Aktywność na całe życie. Polsko-Słowacka platforma kultury fizycznej i promocji zdrowia studentów, okres realizacji od I.I2.2009 do 30.II.20Io. 2. Wielkie Granie. Polsko-słowacka wymiana doświadczeń w dziedzinie sportu akademickiego oraz promocji aktywności fizycznej, okres realizacji od I.07.20II do 30.04.20I2. 3. Diagnostyka w sporcie kluczem do sukcesów polskich i słowackich klubów akademickich, okres realizacji od I.03.2013 do 31.I2.2013.

59 Do tradycji i osiągnięć krośnieńskiego hutnictwa szkła sięgnęły władze Carolina University, składając wizyty u krośnieńskich hutników, a następnie zapraszając właściciela Huty Szkła „Sabina” na warsztaty szklarskie z okazji utworzenia nowej specjalności kształcenia na wydziale sztuki.

60 W festiwalu organizowanym od roku 20I4 uczestniczyło kilkuset studentów i nauczycieli z Chin, Hiszpanii, Portugalii, Rosji, Słowacji, Ukrainy, USA, Węgier. Od 2017 roku festiwal został objęty patronatem Ministra Nauki i Szkolnictwa Wyższego.

61 Twórczą i szeroką działalność i wiele inicjatyw podjęli studenci PWSZ w Białej Podlaskiej, Elblągu, Jarosławiu, Przemyślu, Tarnowie, Wałbrzychu i Zamościu. Ich osiągnięcia zasługują na osobne opracowanie. 
aspekt samorządności studentów, nie zawsze odpowiednio doceniany przez nich samych, czyli na zdobywanie w organizacjach studenckich cennych doświadczeń w zarządzaniu, pracy w grupie, poznawaniu problemów środowiska młodzieżowego, umiejętności wystąpień publicznych, odpowiedzialności, zaradności i sprawności organizacyjnej. Studenci aktywnie pracujący w samorządzie z łatwością znajdują atrakcyjną pracę po ukończeniu studiów, często w uczelni, lub podejmują działalność w samorządach lokalnych.

Mówiąc o PWSZ w Krośnie, oprócz wspomnianych, raczej powszechnych form aktywności studentów, należy podkreślić ambicję podniesienia artystycznej rangi Juwenaliów organizowanych pod nazwą Dni kultury studenckiej. W ich trakcie odbyło się kilka „oxfordzkich” debat, ogniskujących dyskusję na ważne tematy wspólnie z Młodzieżową Radą Miasta Krosna. Studenci mogą się poszczycić najlepiej działającym na Podkarpaciu Klubem Honorowych Dawców Krwi PCK, działalnością w 25. kołach naukowych i organizacją pięciu ogólnopolskich konferencji studenckich kół naukowych. Z okazji jubileuszu I5-lecia uczelni o samorządności studentów napisano:

Działalność studencka widziana w kontekście piętnastu lat rozwoju uczelni musi być postrzegana na tle procesów przemian całego społeczeństwa i systemu edukacji. Taka perspektywa, która odsłania proces rozpadu tradycyjnych więzi rodzinnych i wspólnot lokalnych, stawia przed krośnieńską PWSZ obowiązek tworzenia nowych struktur związanych z projektem społeczeństwa obywatelskiego. Poprzez działalność Samorządu „uczelnia na miejscu” tworzy i pomaga odkryć własne miejsce rosnącej z roku na rok grupie absolwentów. Wypada tu także wspomnieć przynajmniej kilka osób, które sprawie Samorządu poświęcały swój czas i angażowały się w jego działania z rzadko spotykaną energią i poświęceniem. W tym gronie zabraknąć nie może: Dariusza Jurczaka, Arkadiusza Ślączki, Sławomira Stefańskiego, Katarzyny Stopkowicz-Studnickiej, Agnieszki Harmaty. Ich wytrwałej pracy społeczność PWSZ im. Stanisława Pigonia wiele zawdzięcza, a wspólna pamięć o ich wkładzie w życie naszej uczelni jest najlepszym świadectwem dojrzałości ${ }^{62}$.

Studenci zrzeszeni w Klubie Uczelnianym AZS wielokrotnie zdobywali tytuły Akademickich Mistrzów Polski w sportach indywidualnych i drużynowych - wśród nich zaszczytne czterokrotne Akademickie Mistrzostwo Polski w siatkówce kobiet (20I2, 2013, 20I4, 20I5). I, co ważniejsze, AZS zrzeszając kilkuset członków przyczynia się do promowania wielu form aktywności ruchowej, zarówno całorocznej, jak i w czasie wakacyjnych obozów wodnych, żeglarskich i rowerowych. Obserwując rozwój studenckiej aktywności sportowej w ostatnich kilku latach, warto zwrócić uwagę na niepokojące zmniejszenie się uczestnictwa studentów w wakacyjnych formach wypoczynku i szkoleń ze względu na podejmowanie przez nich w tym czasie pracy zarobkowej zarówno w kraju, jak i za granicą. 


\section{Biblioteka}

Biblioteki jako jednostki uczelni zapewniające studentom dostęp literatury do indywidualnych studiów i ich rozwój od początku działalności stanowiły dla władz poważne wyzwanie organizacyjne i finansowe. Ze względu na misję pełnienia roli lokalnej biblioteki naukowej zbiory są udostępnianie na miejscu również czytelnikom spoza uczelni.

W większości państwowych uczelni zawodowych biblioteki były tworzone od podstaw. W uczelniach powstających w ośrodkach, a takich była większość, w których funkcjonowały kolegia nauczycielskie lub nauczycielskie kolegia języków obcych, organy prowadzące, najczęściej Urzędy Marszałkowskie, przekazywały zasoby bibliotek kolegiów dla uczelni, które przejmowały likwidowane w kolegiach studia. Pracownicy organizowanych bibliotek musieli w krótkim czasie opracować politykę gromadzenia zbiorów w celu zapewnienia studentom i pracownikom dostępu do publikacji naukowych i dydaktycznych. O ile organizacja zakupów publikacji nowo wydawanych nie stwarzała większych trudności, to gromadzenie podstawowej literatury przedmiotu i kluczowych dla danej dziedziny podręczników akademickich, nie wznawianych w ostatnich latach, stanowiło często istotny problem. Rozwiązywano go dzięki zakupom antykwarycznym, wypożyczeniom międzybibliotecznym z bibliotek uczelni akademickich i zawieraniu umów z bibliotekami funkcjonującymi w danym mieście. Bardzo często problemy z dostępem do literatury pomagali rozwiązywać wykładowcy, udostępniając studentom własne zbiory, np. publikacje niezbędne do przygotowania prac dyplomowych. Praktyką bardzo często w związku z tym stosowaną było wykonywanie kserokopii całych wydawnictw, bądź ich poszczególnych rozdziałów i wprowadzanie ich do zbiorów biblioteki. Warto pamiętać o tym, że pod koniec XX wieku możliwości tzw. małej poligrafii były jeszcze bardzo ograniczone, a publikowanie wydawnictw w małych nakładach było drogie. Tylko nieliczne publikacje były dostępne w Internecie, do którego dostęp pozostawał ograniczony, ponieważ szerokopasmowa transmisja, dzięki sieci Pionier rozwinęła się po 200 r roku, a w ośrodkach pozbawionych do niej dostępu ze względu na brak infrastruktury nastąpiło to jeszcze później.

Powyższy, krótki rys historyczny pokazuje, jakie problemy należało rozwiązywać, a ponadto stanowi interesujący punkt odniesienia do obecnego stanu bibliotek w państwowych uczelniach zawodowych.

Księgozbiór Biblioteki Głównej Państwowej Wyższej Szkoły Zawodowej im. Stanisława Pigonia w Krośnie powstał z połączenia zbiorów będących własnością bibliotek Kolegium Nauczycielskiego w Krośnie i Nauczycielskich Kolegiów Języków Obcych w Jaśle i Krośnie. W 2002 roku uchwałą Zarządu Województwa Podkarpackiego w Rzeszowie przekazano bibliotece uczelnianej 28070 woluminów i I442 jednostki zbiorów specjalnych. Dzięki systematycznemu uzupełnianiu zbiorów zasoby biblioteki na koniec 2017 roku liczyły 76 o60 woluminów i 5603 jednostek zbiorów specjalnych. Cennym źródłem wzbogacenia zbiorów biblioteki były darowizny dokonane na rzecz 
uczelni m.in. przez Stanisława Bortnowskiego, Stanisława Lisieckiego, Krzysztofa Pleśniarowicza, Fritza Königa i Jacka Lalę.

Znacząco zwiększona została również lista prenumerowanych gazet i czasopism w 200 I roku biblioteka prenumerowała 6I tytułów, w tym 3 obcojęzyczne. Obecnie prenumerata obejmuje i37 tytułów, w tym 6 obcojęzycznych.

Od 20 Io roku biblioteka uczelniana oferuje dostęp do zasobów Wirtualnej Biblioteki Nauki w ramach krajowej licencji akademickiej, której zasoby obejmują:

- ISI Web of Knowledge - Web of Science - tzw. indeksy cytowań: Science Citation Indeks Expanded, Social Science Citation Index, Art \& Humanities Citation Index; Conference Proceedings Citation Index (publikacje z najbardziej znaczących konferencji, sympozjów, seminariów i warsztatów); Journal Citation Reports,

- Science Direct - czasopisma wydawane przez Elsevier Science, w tym spisy treści, dane bibliograficzne, abstrakty oraz pełne teksty artykułów wraz z grafiką

- Springer - czasopisma naukowe i branżowe, książki i opracowania wydawane przez Springera,

- EBSCO Publishing - podstawowy pakiet I2 baz - pełnotekstowych i bibliograficznych,

- SciVerse Scopus - interdyscyplinarna baza abstraktów i cytowań z zakresu nauk matematyczno-przyrodniczych, technicznych, medycznych i humanistycznych,

- Willey-Blackwell - czasopisma z nauk ścisłych, humanistycznych i społecznych wraz $\mathrm{z}$ archiwami od $\mathrm{I} 997$ roku.

Czytelnicy mogą także korzystać z elektronicznych edycji magazynów „Science” i „Nature”.

Dostępne są również: dwie bazy polskich norm Integram 3.0 (z zakresu budownictwa i przemysłu spożywczego) oraz Polska Bibliografia Lekarska (baza bibliograficzna).

Od 2015 roku dla użytkowników biblioteki uczelnianej zostały udostępnione e-booki bazy Ibuk Libra. Ponadto biblioteka oferuje czasowy dostęp do kilku baz danych, zwykle dwa razy w roku.

W czerwcu 20 Io roku oddano do użytku okazały i wielofunkcyjny budynek biblioteki uczelnianej o znacznej przestrzeni, wysokim standardzie technicznym, dobrze i nowocześnie wyposażony, który zapewnia pracownikom i studentom uczelni bardzo dobre warunki do studiowania i pracy naukowo-dydaktycznej. Za najważniejsze udogodnienia dla czytelników należy uznać:

- otwarty wolny dostęp do zbiorów umożliwiający czytelnikowi bezpośredni kontakt ze zbiorami bibliotecznymi, swobodne przeglądanie i wybór materiałów dostęp do zbiorów udostępnianych do wypożyczania,

- 6o miejsc w czytelni (stanowiska jednoosobowe, stoliki do pracy w grupie, stanowiska pozwalające na pozostawienie materiałów własnych w bibliotece oraz miejsca z wygodnymi fotelami stwarzające bardzo komfortowe warunki lektury),

- 40 stanowisk komputerowych w czytelniach internetowych (z dostępem do Internetu, baz danych oraz zasobów Wirtualnej Biblioteki Nauki),

- czytelnie specjalistyczne - multimedialną oraz gazet i czasopism (komfortowe warunki lektury, możliwość przesłuchiwania materiałów audialnych i oglądania materiałów audiowizualnych zapisanych na nośnikach cyfrowych, 
- łatwy i szybki dostęp do źródeł informacji,

- nowoczesną ochronę zbiorów - zastosowanie systemu identyfikacji radiowej RFID usprawnia pracę bibliotekarzy (zabezpieczenie przed kradzieżą, szybkie skontrum i szybkie porządkowanie zbiorów) i umożliwia zastosowanie urządzeń, dzięki którym czytelnik może sam dokonywać wypożyczeń dokumentów lub zwrotów (SelfCheck), - dogodne warunki do prowadzenia działalności promocyjnej - (szkolenia, prezentacje, wystawy) - duża przestrzeń ekspozycyjna w holu biblioteki i na poddaszu oraz możliwość aranżacji wystaw w pomieszczeniach bibliotecznych,

- bezpieczeństwo zbiorów - identyfikacja radiowa RFID oraz system monitoringu CCTV, monitoringu przeciwpożarowego i antywłamaniowego (w budynku biblioteki mieszczą się także zbiory Archiwum uczelnianego).

Zgodnie z zasadą „uczelnia bez barier” w bibliotece zaprojektowano rozwiązania komunikacyjne dostosowane do potrzeb osób niepełnosprawnych i udogodnienia ułatwiające korzystanie ze zbiorów osobom z wadami wzroku i słuchu. Biblioteka zapewnia osobom niepełnosprawnym taki sam dostęp do wiedzy jak osobom pełnosprawnym: dysponuje urządzeniami ułatwiającymi osobom niedowidzącym oraz niepełnosprawnym ruchowo korzystanie z zasobów lub materiałów własnych.

Tytułem uzupełnienia warto podkreślić, że biblioteka, oprócz udostępniania zbiorów, prowadzenia działalności w zakresie informacji naukowej podejmuje również inicjatywy w zakresie organizacji spotkań z twórcami, wystaw artystycznych plastycznych i fotograficznych, popularnonaukowych poświęconych kulturze regionu, a także okolicznościowych związanych, np. z rocznicami historycznymi. Zorganizowano m.in. ekspozycje: Wystawa wspótczesnej grafiki biatoruskiej (2013), Baśnie Andersena w polskiej ilustracji ksiażkowej (2014), Polacy-Ukraincy I939-I947 (2015), Honwedzi i huzarzy na polskiej ziemi. Polowe i inne historie I9I4-I9IS (2015), Dwór polski w starej fotografii (2015) Naczelnik Państwa i Marszatek Polski Józef Pitsudski (1867-1935) (2015), Fantastyka $w$ komiksie. Komiks $w$ fantastyce (2016), Polska ilustracja ksiązkowa dla dzieci i mtodzieży z lat 50.-80. XX wieku (2016), Drewniane cerkwie w polskim i ukrainskim regionie Karpat (2016), Kobiety $w$ nauce (2016), "Zaplute karty reakcji”-polskie podziemie niepodlegtościowe 1944-1956 (2017), Wieś polska $w$ malarstwie i grafice (2017), Matopolski Przetom Wisty z lotu ptaka (2017), Nauka droga do Nobla (20I7).

Powyższy, z konieczności krótki, opis biblioteki i przykładowych form jej działalności, także tych poza udostępnianiem zbiorów, dobrze obrazuje kulturotwórczy aspekt działania tej ważnej agendy uczelni. Istotne jest także to, że biblioteki PWSZ są bardzo często pierwszymi bibliotekami naukowymi w mieście, udostępniającymi swoje zbiory również dla osób spoza środowiska uczelni.

\section{Dziatalność wydawnicza}

Większość PWSZ prowadzi własną działalność i politykę wydawniczą. Dobrze świadczy ona o potencjale naukowym i dydaktycznym uczelni, ułatwia dostęp do skryptów i innych materiałów studentom, a także wzbogaca, często w odkrywczy sposób, liczbę publikacji podejmujących badania lokalnych zjawisk i problemów. W wypad- 
ku państwowych uczelni zawodowych, działalność wydawnicza jest podejmowana, także w trosce o budowanie prestiżu naukowego, dokumentowania ważnych dla środowiska wydarzeń oraz, co niebagatelne, obniżenia kosztów finansowych dostępu studentów do literatury.

Mimo tego, że PWSZ w Krośnie nie utworzono wydawnictwa uczelnianego, to podjęto intensywną działalność wydawniczą. Najważniejszym przedsięwzięciem wydawniczym jest seria Prace Naukowo-Dydaktyczne PWSZ w Krośnie, w której do roku 2018 opublikowano 7I tomów. Zgodnie z nazwą serii najczęściej są to publikacje o charakterze dydaktycznym, opracowane przez pracowników uczelni i sprzedawane studentom po kosztach produkcji. W większej części publikacje zyskują pozytywne opinie i zainteresowanie studentów.

Uczelnia publikuje również wydawnictwa okolicznościowe. Ukazały się księgi jubileuszowe w związku z piątą, dziesiątą i piętnastą rocznicą utworzenia szkoły ${ }^{63}$, wydano prace ofiarowane wykładowcom na kierunku Pielęgniarstwo: Od pediatrii do zdrowia publicznego. Prace ofiarowane prof. dr. hab. n. med. Pawtowi Januszewiczowi, red. Danuta Zarzycka, Józef Ryżko, Krosno 2009; Gastroenterologia zbliża, ksztattuje obyczaje. Prace ofiarowane prof. dr hab. n. med. Józefowi Ryżce, red. Elżbieta Piontek, Danuta Zarzycka, Krosno 20II; Endokrynologia pediatryczna droga rozwoju dla nauk o zdrowiu. Prace ofiarowane prof. dr hab. n. med. Elżbiecie Piontek, red. Renata Rabiasz, Krosno 2016.

Z okazji Dni Przyjaźni Polsko-Węgierskiej w 2009 roku został opublikowany w bogatej szacie edytorskiej, nawiązującej do druków renesansowych, zbiór wierszy Pawła z Krosna Amicitia - Baratsag - Przyjaźñ ${ }^{64}$ w językach: łacińskim, węgierskim i polskim. W 2005 roku wydano z okazji 25-lecia Solidarność 1980-2005. Pamięć. Historia. Tożsamość oraz Obejmując sercem tę ziemię... Pamięci Ojca Świętego Jana Pawta II.

Większość tomów wychodzi w jednolitej szacie edytorskiej, zdarzają się jednak pozycje, które zyskują odrębny kształt graficzny - choćby ze względu na tematykę czy artystyczny charakter publikacji - jak wspomniany zbiór wierszy Pawła z Krosna, czy monografie pokonferencyjne związane z zabytkami, historią i sztuką Krosna Kościót parafialny Świętej Trójcy w Krośnie w panoramie dziejów miasta ${ }^{65}$, Literackie Krosno ${ }^{66}$. Wymienione tytuły odzwierciedlają zaangażowanie społeczności uczelni w obchody rocznic ważnych wydarzeń uczelnianych i państwowych.

Bardzo dużym zainteresowaniem czytelników cieszą się monografie wydane w związku z konferencjami naukowymi Rośliny zielarskie, kosmetyki naturalne

63 Państwowa Wyższa Szkoła Zawodowa w Krośnie. 5 lat 1999-2004, Krosno 2004, io lat PWSZ w Krośnie 1999-2009, Krosno 2009, Państwowa Wyższa Szkoła Zawodowa imienia Stanisława Pigonia w Krośnie 1999-20I4, Krosno 20I4. Podobne, rocznicowe inicjatywy wydawnicze podejmowały wszystkie PWSZ w Polsce.

64 Amicitia-Baratsag-Przyjań, Krosno MMIX.

65 Kościót parafialny Świętej Trójcy w Krośnie w panoramie dziejów miasta, red. P. Łopatkiewicz, Krosno 2012.

66 Literackie Krosno, red. G. Przebinda, J. Kułakowska-Lis, Krosno 2016. 
i żywność funkcjonalna ${ }^{67}$. Uczelnia wydaje także czasopismo - „Biuletyn Państwowej Wyższej Szkoły Zawodowej w Krośnie” - współredagowany przez pracowników i studentów, ukazujący się w cyklu kwartalnym

Działalność wydawnicza pozwalająca na utrwalanie myśli i dokonań wpisuje się w misję PWSZ im. Stanisława Pigonia w Krośnie. Patron - wybitny historyk literatury i edytor, zobowiązuje do dbałości również o ten aspekt funkcjonowania uczelni.

\section{Wspótpraca z uczelniami akademickimi}

Jest oczywistym twierdzenie, że bez zaangażowania rektorów, dziekanów, senatów i rad wydziałów, a przede wszystkim, wielu pracowników uczelni akademickich ogólnopolski projekt pod nazwą: utworzenie i rozwój działalności państwowych uczelni zawodowych nie miałby żadnych szans na sukces. Dla wszystkich osób i podmiotów zaangażowanych w proces tworzenia tychże uczelni oczywistym było, że mogą one rozpocząć działalność jedynie przy wydatnej pomocy uczelni akademickich, realizowanej w formie patronatu lub umów o współpracy. Pomoc ta często obejmowała w pierwszym etapie poparcie organów kolegialnych dla utworzenia uczelni zawodo$w^{6}{ }^{68}$, a następnie także deklarację woli w formie listu intencyjnego lub umów opisujących planowany zakres współpracy. W umowach rektorzy uczelni akademickich deklarowali, m. in.: współpracę przy opracowaniu planów i programów studiów, udział pracowników naukowo-dydaktycznych w realizacji zajęć dydaktycznych, możliwość udziału pracowników uczelni zawodowych w badaniach naukowych i umożliwianie zdobywania stopni naukowych, współorganizację konferencji i, co szczególnie ważne, możliwość kontynuowania studiów na poziomie magisterskim dla absolwentów. Umowy były zawierane na okres pięciu lat, a następnie przedłużane, a w ostatnich latach, po pozytywnych doświadczeniach współpracy, są podpisywane na czas nieokreślony. Dobrym argumentem potwierdzającym wartość i efektywność tejże współpracy jest to, że żadna z nich nie została wypowiedziana, aczkolwiek w kilku przypadkach wprowadzono zmiany w ich treści obejmujące zakres wzajemnych zobowiązań ${ }^{69}$.

Ważniejsze jednak od treści umów było rzeczywiste zaangażowanie władz Uniwersytetu Jagiellońskiego, Akademii Górniczo-Hutniczej i Wyższej Szkoły Pedagogicznej w Rzeszowie (od 200I roku Uniwersytetu Rzeszowskiego) pozwoliło, zwłaszcza w pierwszym okresie działalności, na sprostanie wymogom akredytacji, opracowanie planów i programów studiów i rozpoczęcie działalności dydaktycznej. W kolejnych latach, poszukując możliwości poszerzania oferty studiów, zainicjowano współpraca

67 Rośliny zielarskie, kosmetyki naturalne i żywność funkcjonalna, Krosno-Wrocław, 20I3, 20I4, 20I5, 20I6, 20I7. Pięć monografii związanych w konferencjami naukowymi organizowanymi przez PWSZ w Krośnie we współpracy z Uniwersytetem Przyrodniczym we Wrocławiu.

68 Senat UJ na posiedzeniu w dniu I6 grudnia I998 roku, Rektor Akademii Górniczo-Hutniczej 29 grudnia 1998, Rada Wydziału Wyższej Szkoły Pedagogicznej w Rzeszowie 7 lipca I998, Instytut Pedagogiki UJ II maja I998.

69 Zmiany obejmowały najczęściej ograniczenia w udzielaniu zgód Rektorów uczelni partnerskich na zatrudnienie w PWSZ jako drugim miejscu pracy. 
z Politechniką Rzeszowską (2003), Akademią Wychowania Fizycznego im. A. Czecha w Krakowie (2003), Akademią Medyczną im. Prof. F. Skubiszewskiego w Lublinie, później Uniwersytetem Medycznym (2005), Uniwersytetem Przyrodniczym we Wrocławiu (20I2), Uniwersytetem Ekonomicznym w Krakowie (20I4), Uniwersytetem Papieskim JPII w Krakowie (20I5), Warszawskim Uniwersytetem Medycznym (20I5).

Można w tym miejscu postawić pytanie, czy współpraca z uczelniami akademickimi wpisuje się w kulturotwórczą rolę uczelni zawodowych? Odpowiedź musi być jednoznacznie pozytywna - w ramach współpracy między uczelniami dokonuje się transfer doświadczeń z ośrodków akademickich do mniejszych miast i dzięki temu konstytuuje się w nich nowe wartości kultury i naukowe przedsięwzięcia bogatsze w wyniku współdziałania ${ }^{70}$.

\section{Badania naukowe w PWSZ}

Ustawodawca nie nałożył na PWSZ statutowego obowiązku prowadzenia badań naukowych, ograniczając ich działalność do realizowania obowiązków dydaktycznych, co skutkowało nieprzyznaniem tym uczelniom środków budżetowych na działalność naukową. Mimo tego ograniczenia uczelnie wdrażały różne formy działalności naukowej samodzielnie bądź we współpracy z uczelniami akademickimi. Zainteresowania naukowe pracowników PWSZ w oczywisty sposób wiążą się z kierunkami prowadzonych studiów i z miejscem funkcjonowania uczelni. Ze względu na źródła finansowania badania naukowe realizowane w PWSZ można pogrupować następująco:

\section{Badania wtasne pracowników}

Najważniejszym impulsem do inicjowania pracy naukowej wśród pracowników uczelni, zwłaszcza w pierwszych latach działalności, były potrzeby zapewnienia minimów kadrowych dla prowadzonych specjalności, a później kierunków studiów. Osiągnięciu tego celu sprzyjały ambicje i plany naukowe młodszych pracowników oraz dobre warunki współpracy z uczelniami akademickimi, a także zatrudnianie samodzielnych pracowników nauki, którzy kierowali rozwojem naukowym młodszych kolegów, występując w roli opiekuna lub promotora pracy naukowej. Te starania wynikały z przekonania, że warunkiem samodzielnego funkcjonowania uczelni jest wykształcenie własnej kadry, przynajmniej do stopnia doktora. Koszty badań były finansowane lub dofinansowywane przez uczelnie ze środków własnych, bądź finansowane przez pracowników ze środków własnych, co stanowiło często poważne obciążenie finansowe. Realizację części badań umożliwiały również uczelnie akademickie na podstawie umów o współpracy, udostępniając laboratoria i sprzęt

70 Dobrym przykładem ilustrującym efekty współpracy są konferencje naukowe Rośliny zielarskie, kosmetyki naturalne i żywność funkcjonalna organizowane w Krośnie od 2014 roku wspólnie przez Państwową Wyższą Szkołę Zawodową w Krośnie i Uniwersytet Przyrodniczy we Wrocławiu. Mimo determinacji organizacyjnej PWSZ w Krośnie bez zaangażowania pracowników naukowych UP we Wrocławiu, a także innych uczelni akademickich konferencja nie osiągnęłaby ogólnopolskiego znaczenia. Podobnie, jak rocznicowa konferencja poświęcona Stanisławowi Pigoniowi w 2008 roku, czy międzynarodowe konferencje Across borders i wiele innych przedsięwzięć naukowych. 
badawczy niezbędny do wykonywania pomiarów. Spore obciążenie finansowe dla uczelni zawodowych stanowiły również koszty przeprowadzenia przewodów doktorskich w uczelniach akademickich. Często przekraczały one kwotę Io tysięcy złotych za pojedyncze postępowanie. $Z$ perspektywy prawie dwudziestoletniej historii uczelni można ocenić, że tego rodzaju działalność przyniosła bardzo dobre efekty, umożliwiając uczelniom rozwój własnej kadry dydaktycznej i wypełnienie obowiązujących minimów kadrowych przez pracowników zatrudnionych na podstawowym miejscu pracy. Wyniki badań publikowane w wydawnictwach uczelnianych często wykorzystywano w działalności dydaktycznej. Takie podejście pozwalało podnosić jakość kształcenia w połączeniu z rozwojem naukowym pracowników. Nie ulega wątpliwości, że dla osiągania dobrych wyników dydaktycznych konieczna jest aktywność naukowa pracowników. Potwierdzają ją wyniki okresowych ocen pracowników prowadzonych przez uczelnię i, co ważne, opinie studentów.

2. Badania naukowe realizowane w ramach grantów indywidualnych lub zespotowych.

Zespołowe lub indywidualne wnioski o przyznanie środków na realizację badań naukowych w obszarach bliskich kierunkom prowadzonych studiów zostały zrealizowane w wielu PWSZ. Sprzyjały temu zainteresowania i doświadczenie naukowe pracowników oraz liczne konkursy na badania ogłaszane przez władze ministerstw lub wojewódzkie władze samorządowe. Bardzo często przedmiotem badań były lokalne zjawiska lub problemy, które nie zostały podjęte przez pracowników uczelni akademickich lub instytutów naukowych.

W PWSZ w Krośnie zostały zrealizowane zespołowe badania dotyczące:

- wpływu działalności kopalń ropy naftowej na stan środowiska naturalnego i warunki eksploatacji wód leczniczych ${ }^{71}$,

- standardów ekologicznego chowu zwierząt jeleniowatych ${ }^{72}$,

- możliwości aktywizacji gospodarczo-turystycznej województwa podkarpackiego ze względu na walory przyrodniczo-krajobrazowe ${ }^{73}$.

Pracownicy uczelni zrealizowali również wiele badań i usług eksperckich na zamówienie Regionalnej Dyrekcji Lasów Państwowych i podkarpackich gmin. Łączna

71 Zrealizowane zostały badania zespołowe na temat: Ocena wptywu wyrobisk górniczych początków górnictwa naftowego (kopanek) na środowisko, umowa z dnia I8.IO.2007 na podstawie decyzji nr 3372/B/ To2/2007/33 z dnia 25.07.2007 i Ocena wptywu naturalnej migracji przypowierzchniowej substancji weglowodowych na warunki eksploatacji wód mineralnych $w$ uzdrowiskach na przyktadzie I wonicza-Zdroju, umowa z dnia 26.05.20II na podstawie decyzji nr 2528/B/To2?20II/40 z dnia 4.02.20II.

72 Ze środków Ministerstwa Rolnictwa i Rozwoju Wsi sfinansowane zostały badania: Okré́lenie dobrych praktyk, standardów i zasad utrzymania przy ekologicznym chowie zwierząt jeleniowatych z przeznaczeniem na produkcje mięsa, decyzja z dnia I8.05.20II i Określenie dobrych praktyk, standardów i zasad utrzymywania przy ekologicznym chowie zwierząt jeleniowatych z przeznaczeniem na produkcję mięsa, decyzja z dnia 7.05.2012.

73 Seria trzech badań na temat: Program aktywizacji gospodarczo-turystycznej województwa podkarpackiego poprzez promocje cennych przyrodniczo i krajobrazowo wskazanych terenów tąkowo-pastwiskowych z zachowaniem bioróżnorodności w oparciu o naturalny wypas, zrealizowano w latach 2013, 20I4, 2016 w konkursie ogłoszonym przez Marszałka Województwa Podkarpackiego. 
wartość badań zrealizowanych w ramach grantów zespołowych i indywidualnych przekroczyła I mln złotych.

3. Badania naukowe zlecone przez zewnętrzne podmioty $w$ ramach grantów finansowanych ze środków UE.

W ostatnich latach motywacją do zlecania badań naukowych były również wymogi innowacyjności projektów realizowanych przez przedsiębiorców ze środków europejskich, a także ze środków własnych podmiotów gospodarczych. Poważną barierą ograniczającą ich rozwój jest brak doświadczenia pracowników uczelni, obciążenie obowiązkami dydaktycznymi, brak zespołów badawczych, jak też niewielkie zainteresowanie przedsiębiorców, zwłaszcza jeżeli dotyczy to badań finansowanych ze środków własnych. Jednak rozwijanie współpracy naukowo-badawczej z podmiotami z otoczenia gospodarczego uczelni jest poważnym zadaniem warunkującym wdrażanie innowacyjnych technologii i poszukiwanie optymalnych rozwiązań organizacyjnych. Realizacja takich badań umożliwia pracownikom uczelni zdobywanie dodatkowych doświadczeń, pozwala na wdrażanie studentów do przeprowadzania części badań, rozwija formy zajęć praktycznych.

Dla przykładu, do najciekawszych nowatorskich opracowań zrealizowanych przez pracowników uczelni dla podmiotów zewnętrznych należały: Opracowanie zatożeń recepturowych z wykorzystaniem super lecytyny, hydrolizatów biatek poekstrakcyjnych biatka i żóttka oraz bioaktywnych substancji pomocniczych do wytwarzania suplementów diety nowej generacji, z uwzględnieniem potencjalnych możliwości niezbędnych do realizacji zadania, dla Uniwersytetu Przyrodniczego we Wrocławiu, 20I2; Opracowanie dokumentacji niezbędnej do rozpoczęcia innowacyjnej linii produktów nutraceutycznych, dla Greenground, 2013; Opracowanie sktadu i przygotowanie receptury dla innowacji kosmetycznej, dla Kosmetyki DLA, 2014.

Podsumowując naukowe osiągnięcia pracowników uczelni, należy wysoko ocenić ich kulturotwórczą rolę i można przypuszczać, że będą on twórczo i efektywnie rozwijane w nawiązaniu do wzorów wypracowanych w USA oraz ze względu na zapisy Strategii na rzecz odpowiedzialnego rozwoju Mateusza Morawieckiego i planowane zmiany w prawie o szkolnictwie wyższym. Jednak w oparciu o dotychczasowe doświadczenia i niewielki jeszcze potencjał uczelni można stwierdzić, że będzie to proces długoletni, warunkowany ponadto rozwiązaniami ustawowymi, regulującymi zasady finansowania badań w oparciu o np. ulgi podatkowe ${ }^{74}$.

Ważnym i obiektywnym wyznacznikiem osiągnięć naukowych publicznych uczelni zawodowych są wyniki parametryzacji naukowej przeprowadzonej w roku akademickim 20I6/20I7 - sześć PWSZ uzyskało kategorię naukową75

74 Przepisy ustawy o podatku dochodowym od osób fizycznych, Art. 26e przewidują możliwości odliczeń od podstawy obliczenia podatku koszty uzyskania przychodów poniesionych na działalność badawczo-rozwojową. Dz. U. z 2016 r. poz. 2032; ostatnia zmiana w Dz. U. z 2017 r. poz. 2494.

75 PWSZ w Opolu Wydział Fizjoterapii, kat. A; PWSZ Białej Podlaskiej Wydział Nauk Ekonomicznych i Technicznych, kat. A, Wydział Nauk o Zdrowiu i Nauk Społecznych, kat. B; PWSZ w Elblągu kat. C; PWSZ w Krośnie, kat. C; PWSIP w Łomży kat C; PWSZ w Nysie kat. C. 


\section{Baza materialna uczelni}

Oceny bazy dydaktycznej państwowych wyższych szkół zawodowych dokonywane przez władze ministerialne, ekspertów Polskiej Komisji Akredytacyjnej i, co najważniejsze, przez jej użytkowników - studentów i nauczycieli są w zdecydowanej większości bardzo wysokie, a nawet entuzjastyczne. Można bez ryzyka stwierdzić, że jej przygotowanie można zaliczyć do najważniejszych osiągnięć w rozwoju wyższego szkolnictwa zawodowego w Polsce i może być ona przedmiotem dumy władz uczelni, władz Ministerstwa Nauki i Szkolnictwa Wyższego (do 5 maja 2006 Ministerstwo Edukacji Narodowej), a także władz samorządowych.

Obecnie niemal wszystkie PWSZ dysponują zmodernizowanymi, często zabytkowymi, o wysokich walorach architektonicznych i historycznych ${ }^{76}$, lub nowymi obiektami optymalnie wyposażonymi w sprzęt laboratoryjny, zapewniający bardzo dobre warunki do prowadzenia zajęć dydaktycznych i realizowania badań naukowych. Warto docenić hojność i determinację ówczesnych władz samorządowych wojewódzkich i powiatowych, które przekazywały nieruchomości dla uczelni (często w organizacji). W miastach, aspirujących do utworzenia uczelni, wobec potrzeb pilnego przygotowania obiektów przed inauguracją pierwszego roku akademickiego, przeznaczano na ich siedziby zespoły nieużywanych już koszar ${ }^{77}$, budynki oświatowe (np. obiekty likwidowanych kolegiów nauczycielskich) lub administracyjne. Tylko w nielicznych wypadkach państwowe wyższe szkoły zawodowe utworzono w obiektach uczelni wyższych ${ }^{78}$. Warto nadmienić, że przejmowane obiekty w zdecydowanej większości wymagały remontów i modernizacji, można bez ryzyka więc stwierdzić, że władze samorządowe przeznaczały je dla uczelni z ulgą, a zarazem nadzieją, że nowi właściciele skutecznie i w krótkim czasie adaptują je do nowych celów ${ }^{79}$. Ponieważ miałem przyjemność poznać obiekty większości PWSZ w kraju, mogę odpowiedzialnie stwierdzić, że posiadają one bazę dydaktyczną w pełni odpowiadającą wymogom uczelnianej dydaktyki. Dotyczy to zwłaszcza wyposażenia laboratoriów, zaprojektowanych i wyposażonych tak, aby w pełni umożliwiały realizację praktycznego profilu kształcenia ${ }^{80}$.

Osiagnięcia materialne publicznych uczelni zawodowych, zrealizowane w okresie minionych dwudziestu lat sa imponujące, wartość naktadów inwestycyjnych, która, jak

76 Krosno, Legnica, Przemyśl, Zamość.

77 W adaptowanych obiektach powojskowych znalazły siedzibę uczelnie w Gorzowie, Legnicy, Sanoku, Tarnowie. Wbrew powszechnym, a nawet entuzjastycznym opiniom popierającym zamianę koszar na uczelnię, jej zwolennikiem byłbym jedynie w sytuacji, gdyby następowała w wyniku globalnego porozumienia i wdrożenia.

78 PWSZ w Elblągu powstała w miejsce zlikwidowanej filii Politechniki Gdańskiej.

79 Chlubny wyjątek stanowi przykład PWSZ w Tarnowie, dla której władze miasta zleciły remont i adaptację budynku koszar przy ul. A. Mickiewicza i gotowy do użytkowania przekazały władzom uczelni przed inauguracją jej działalności.

80 Większość wyposażenia laboratoryjnego została zakupiona w ramach realizacji wojewódzkich programów operacyjnych w latach 2008-20I4 i 20I4-2020 - są to urządzenia nowe, zaawansowane technologicznie. 
wynika z danych GUS, do końca 2016 roku wyniosta tącznie 1999,3 mln zt. (...) Wartość kluczowych inwestycji (projektów infrastrukturalnych) zrealizowanych do końca 2015 roku wynosita 1353,3 mln. zt, co stanowito 4,4\% wartości kluczowych inwestycji w naukę i szkolnictwo wyższe we wszystkich uczelniach w kraju ${ }^{81}$. Dzięki tym środkom pochodzącym w większości z funduszy europejskich uczelnie te dysponują nowoczesnymi, dobrze wyposażonymi w sprzęt do zajęć dydaktycznych i badań naukowych obiektami.

W roku 1998 Krosno nie dysponowało obiektami nadającymi się do wykorzystania na siedzibę uczelni prowadzącej studia na kilku kierunkach licencjackich i inżynierskich. Budynek przy ul. ks. Piotra Skargi, część budynku i hala sportowa przy ul. Stanisława Wyspiańskiego oraz kilka sal dydaktycznych w kamienicy przy Rynku 5, będące siedzibą Kolegium Nauczycielskiego i Nauczycielskiego Kolegium Języków Obcych, nie stanowiły odpowiedniej i wystarczającej bazy dla planowanej działalności. Natomiast przekazane uczelni w formie darowizny obiekty przy ul. Kazimierza Wielkiego 4, 6, 8, kamienice przy Rynku I i Ia, budynek dawnej Szkoły Podstawowej nr I2 przy ul. Stanisława Wyspiańskiego I2 oraz budynki po Zespole Szkół Rolniczych przy ul. J. Dmochowskiego I2, nieużytkowane przez wiele lat, w większości zdewastowane, nadawały się jedynie do wyburzenia, posiadały jednak wartość historyczną i były pod ochroną konserwatora zabytków. Konserwatorski nadzór oraz troska władz uczelni o zachowanie materialnego dziedzictwa przeszłości Krosna sprawiły, że podjęty został długotrwały i kosztowny proces ich odnowienia i modernizacji. Realizowany etapowo, w miarę uzyskiwania środków finansowych z Ministerstwa Edukacji Narodowej, a następnie Ministerstwa Nauki i Szkolnictwa Wyższego, środków przekazanych przez Gminę Krosno w latach 2000-2004, proces inwestycyjny został pomyślnie zakończony w 2012 roku, dzięki uzyskaniu znaczących dotacji ze środków europejskich w ramach Programu Operacyjnego Rozwój Polski Wschodniej i Regionalnego Programu Operacyjnego Województwa Podkarpackiego. W 2018 roku baza dydaktyczna uczelni obejmuje cztery zespoły obiektów dydaktycznych oraz dwie zabytkowe kamienice, w których mieści się administracja uczelni. Łączna powierzchnia obiektów uczelni wynosi 31 $900 \mathrm{~m}^{2}$. Dziś władzom uczelni ówczesny trud inwestycyjny wynagradzają zespoły Polskiej Komisji Akredytacyjnej, oceniające bazę dydaktyczną wyróżniająco.

Z kronikarskiej rzetelności warto przypomnieć obiekty najcenniejsze kulturowo.

I. Spośród zabytkowych budynków przy ul. Kazimierza Wielkiego 4, 6, 8 najcenniejszy historycznie i architektonicznie jest budynek kolegium jezuickiego - działającego w Krośnie w latach I633-I773. Posadowiony na wewnętrznym założeniu średniowiecznych murów obronnych, budynek kolegium został starannie odrestaurowany w latach 2003-2005 i należy do najcenniejszych, zachowanych świeckich obiektów staromiejskiej zabudowy miasta. Po przyjęciu przez uczelnię imienia Stanisława Pigonia, budynkowi nadano uroczyście nazwę Collegium Pigonianum i umieszczono na nim brązową, zaprojektowaną przez artystę rzeźbiarza Macieja Syrka płaskorzeźbę. 
W uroczystym jej odsłonięciu uczestniczył m.in. prof. Franciszek Ziejka, wówczas Rektor Uniwersytetu Jagiellońskiego.

2. Rektorat i Biblioteka. Starannie odnowione dwie mieszczańskie, szesnastowieczne kamienice mieszczą siedzibę rektora i administrację uczelni, a zintegrowany z nimi budynek biblioteki architektonicznie dopełnia tę część staromiejskiej zabudowy krośnieńskiego Rynku. Udane połączenie tradycji i urody architektonicznej XVI-wiecznych kamienic z nowoczesnością i funkcjonalnością biblioteki zapewnia studentom i pracownikom uczelni znakomite warunki do pracy, a mieszkańcom Krosna i odwiedzającym je turystom przywraca część dawnej świetności królewskiego miasta.

3. Pięknie położony, w otoczeniu zabytkowego drzewostanu, odrestaurowany i zmodernizowany w latach 2009-20I2 zespół budynków dawnej Szkoły Rolniczej, założonej w I897 roku, w czasach zaboru austriackiego, w harmonijny sposób łączy wzniesione w końcu XIX wieku obiekty z nowoczesną infrastrukturą auli uczelnianych. Budynki Szkoły Rolniczej nie przedstawiają wybitnych walorów architektonicznych, lecz przypominają o ponadstuletniej tradycji kształcenia zawodowego w tym miejscu.

Narracja na temat obiektów dydaktycznych PWSZ zasługuje na rozwinięcie, stanowi bowiem inspirujący i budujący przykład twórczych inicjatyw zrealizowanych w kilkudziesięciu miastach przez nowy typ uczelni wyższych przy ambitnym i twórczym zaangażowaniu władz uczelni, polityki Ministerstwa (MEN i MNiSW), marszałków województw i władz miejskich. Dzięki nim w relatywnie krótkim czasie została rozbudowana imponująca infrastruktura dydaktyczna i naukowa dobrze służąca zrównoważonemu rozwojowi Polski.

Niemal dwudziestoletnie doświadczenia nowej kategorii uczelni państwowych prowadzących działalność na terenie całego kraju upoważniają do sformułowania ogólnych wniosków, tym bardziej, że wpisały się one trwale w system szkolnictwa wyższego, a ich działalność jest najczęściej oceniana pozytywnie. Oceny formułowane przez Polską Komisję Akredytacyjną są wysokie. Za inny ogólnopolski probierz osiągnięć PWSZ można uznać ogólnopolski ranking szkół wyższych organizowany do roku 2014 przez dziennik „Rzeczpospolita” i „Perspektywy”, a w następnych latach przez „Perspektywy”. Wielość kryteriów uwzględnianych w rankingu pozwala dokonywać wszechstronnej oceny efektywności uczelni.

Podsumowując refleksję na temat kulturotwórczej roli publicznych wyższych szkół zawodowych w okresie ich dotychczasowej działalności należy z przekonaniem stwierdzić, że wniosły one do polskiego szkolnictwa wyższego szereg interesujących rozwiązań dydaktycznych, naukowych i inwestycyjnych. Przymiotnik „zawodowe” wpisany trwale w nazwę uczelni, jednoznacznie podkreśla najważniejsze przesłanie ich misji, czyli zapewnienie możliwie najlepszych warunków do kształcenia zapewniającego zarówno rozwój intelektualny studentów, jak i przygotowanie ich do pracy zawodowej. Absolwenci uczelni zawodowych w zdecydowanej większości znajdują zatrudnienie na stanowiskach wymagających praktycznych umiejętności. Ci absolwenci, którzy, 
oprócz przygotowania zawodowego, oferują pracodawcy znajomość języka obcego, zawodową kreatywność i wolę doskonalenia zawodowego, osobistymi karierami poświadczają wartość i jakość funkcjonowania uczelni. Społecznym zjawiskiem poświadczającym tę efektywność jest duże zainteresowanie studiami niestacjonarnymi osób czynnych zawodowo i podejmujących studia wyższe w celu zdobycia wiedzy i umiejętności zapewniających im lepszą pozycję na rynku pracy. Warte podkreślenia jest również to, że aktywni zawodowo studenci studiów niestacjonarnych wykazują się dużym zaangażowaniem i bardzo często osiągają lepsze wyniki niż studenci stacjonarni. Kariery zawodowe w żadnym stopniu nie ograniczają absolwentom możliwości podejmowania studiów drugiego stopnia w uczelniach akademickich.

Innym, nie mniej istotnym, składnikiem wykształcenia wyższego, działalności dydaktycznej i wychowawczej uczelni jest uświadomienie studentom powinności społecznych, kształtowanie tożsamości narodowej i troski o dziedzictwo kulturowe zawarte w centrum kultury ${ }^{82}$. Jednak proces definiowania, a tym bardziej zinternalizowania wzorów zachowań, etosu, idei i postaw obowiązujących absolwentów studiów wyższych jest bardzo trudny do osiągnięcia w świecie przeoranym postmodernistycznym przyzwoleniem na każdą prawdę i każde zachowanie - umiarkowany sceptycyzm w tym zakresie odnosi się do całego szkolnictwa wyższego.

Podsumowując osiągnięcia i znaczenie Państwowych Wyższych Szkół Zawodowych w pierwszym dwudziestoleciu działalności, za najważniejsze, znaczące zarówno lokalnie, jak i dla zrównoważonego rozwoju całego kraju należy uznać następujące efekty ich działalności.

I. Powstanie i rozwój samodzielnych instytucji naukowo-dydaktycznych w miastach średniej wielkości (30-Ioo tys. mieszkańców), w których nie było tradycji kształcenia na poziomie studiów wyższych, co w znaczącym stopniu wpłynęło na ich rozwój urbanistyczny, gospodarczy i demograficzny.

2. Budowa i wyposażenie infrastruktury dydaktycznej, naukowej, sportowej i socjalnej uczelni. Wykorzystanie środków finansowych publicznych i europejskich na cele inwestycyjne przyczyniło się do zrównoważonego rozwoju mniejszych ośrodków miejskich.

3. Zapobieganie wykluczeniu społecznemu poprzez umożliwienie zdobywania wiedzy, umiejętności i kompetencji społecznych w celu zdobycia satysfakcjonującej pracy zawodowej i awansu społecznego. Oznacza to również zwiększenie szans edukacyjnych dla mniej zamożnej młodzieży, która często nie mogła podejmować studiów wyższych z powodów finansowych. W wielu wypadkach studenci PWSZ to pierwsi historycznie studenci w wielu rodzinach zamieszkujących małe miasta i wsie. Istotne jest również podniesienie współczynnika skolaryzacji, nie tylko w odniesieniu do statystyki krajowej, lecz do środowiska lokalnego (zwłaszcza wsi).

82 Centrum kultury jest to zintegrowany zbiór centralnych (rdzennych) wartości kulturowych i utrwalających je wytworów oraz ukształtowane w związku z nimi wzory reakcji uczuciowych, struktury myślowe, wzory międzyosobowych kontaktów wewnątrz społeczeństwa, jak też tego społeczeństwa z innymi społeczeństwami. Zob. L. Dyczewski, Kultura polska w procesie przemian, TN KUL, Lublin 1993 , s. 6I i nast. 
4. Tworzenie lokalnego środowiska naukowego oraz sieci powiązań i współpracy $\mathrm{z}$ akademickimi uczelniami wyższymi w zakresie: badań naukowych, uzyskiwania stopni naukowych przez pracowników PWSZ, konferencji naukowych podejmujących lokalną problematykę, a także prowadzenie badań naukowych na rzecz instytucji miejscowych.

5. Kształtowanie samorządności studenckiej i odpowiedzialności społecznej - inspirowanie studentów do działalności naukowej, kulturalnej i sportowej; podejmowanie na rzecz lokalnej społeczności inicjatyw charytatywnych i wolontariatu.

6. Wykształcenie ponad 294 tys. absolwentów, w większości na poziomie pierwszego stopnia studiów. Uczelnie poprzez kształcenie praktyczne i „zamawiane”, zgodne z oczekiwaniami pracodawców, studia dualne, realizację praktyk zawodowych, w wymiarze co najmniej Is tygodni przygotowują studentów do dobrego startu na rynku pracy, umożliwiając im rozpoczęcie indywidualnych karier zawodowych. Nie należy jednak bagatelizować krytycznych opinii o ograniczaniu w czasie studiów pierwszego stopnia teoretycznych podstaw wiedzy ${ }^{83}$.

7. Transfer publicznych środków finansowych do mniejszych ośrodków na cele inwestycyjne infrastruktury uczelnianej oraz społeczne np. stypendia socjalne, naukowe i specjalne ułatwiające podejmowanie i kontynuowanie studiów wyższych pierwszego stopnia.

8. Różne formy popularyzowania osiągnięć nauki, komentowanie ważnych, aktualnych problemów społecznych i historycznych kraju i współczesnej cywilizacji zarówno w czasie konferencji naukowych, jak i w cyklach wykładów tematycznych. Upowszechnianie osiągnięć nauki, nawet $\mathrm{w}$ formach popularnonaukowych, przyczynia się do podniesienia poziomu wiedzy w społeczeństwie, inspiruje lokalne społeczności do dyskursu i refleksji.

9. Dobrze rozwinięta współpraca z placówkami oświatowymi różnych szczebli realizowana w formie otwartych wykładów, warsztatów i zajęć laboratoryjnych, jak i w rocznych cyklach, np. Akademia Młodych, obejmujących zajęcia artystyczne, wiedzę o zdrowiu i kulturze fizycznej oraz naukach stosowanych. Służą one rozbudzaniu zainteresowań, integracji uczniów z uczelnią oraz umożliwiają uczniom udział w zajęciach laboratoryjnych, przeprowadzenie eksperymentów i uświadamiają zaawansowanie technologiczne aparatury badawczej.

Io. Rozwijająca się, zwłaszcza w ostatnich pięciu latach, współpraca z podmiotami gospodarczymi, interesariuszami zewnętrznymi uczelni, przy wsparciu władz uczelni akademickich, pozwala mieć nadzieję na powstanie lokalnych sieci powiązań przemysłu i wdrożeń wspólnych rozwiązań innowacyjnych.

Dwudziestoletnie doświadczenia państwowych uczelni zawodowych, będących $\mathrm{w}$ istocie śmiałym eksperymentem realizowanym przez Ministerstwo Nauki i Szkol-

Zastrzeżenie tym bardziej istotne, że uczelnie akademickie, rekrutując na studia drugiego stopnia, kierują się niemal wyłącznie kryterium liczby studentów, a plany i programy tych studiów nie zawsze uwzględniają teoretyczne treści kształcenia i przygotowanie studenta do podejmowania samodzielnej pracy badawczej. 
nictwa Wyższego, uczelnie akademickie i lokalne społeczności, stanowią wystarczającą perspektywę do wartościowania i sformułowania oceny efektów ich działalności. Ocena ta powinna stanowić impuls do rzeczowej dyskusji, a nie ograniczyć się, jak to często bywa, do jubileuszowych, pochwalnych laurek i świętowania osiągnięć. Procedowanie w Sejmie RP ustawy o szkolnictwie wyższym, poprzedzone wielomiesięcznymi konsultacjami służącymi lepszemu zrozumieniu problemów szkolnictwa wyższego w Polsce, musi stanowić inspirację do dyskusji o kulturotwórczej roli uniwersytetów, politechnik, państwowych wyższych szkół zawodowych, a także uczelni prywatnych. 